Article

\title{
Biocidal Effectiveness of Selected Disinfectants Solutions Based on Water and Ozonated Water against Listeria monocytogenes Strains
}

\author{
Krzysztof Skowron ${ }^{1, *}$, Ewa Wałecka-Zacharska ${ }^{2}$, Katarzyna Grudlewska ${ }^{1}$, Agata Białucha ${ }^{1}$, \\ Natalia Wiktorczyk ${ }^{1}$ (D), Agata Bartkowska ${ }^{1}$, Maria Kowalska ${ }^{3} \mathbb{D D}^{D}$, Stefan Kruszewski ${ }^{4}$ and \\ Eugenia Gospodarek-Komkowska ${ }^{1}$ \\ 1 Department of Microbiology, Nicolaus Copernicus University in Toruń, L. Rydygier Collegium Medicum in \\ Bydgoszcz, 9 M. Skłodowska-Curie St., 85-094 Bydgoszcz, Poland; katinkag@gazeta.pl (K.G.); \\ agatabialucha@wp.pl (A.B.); natalia12127@gmail.com (N.W.); agata.bartkowska@o2.pl (A.B.); \\ gospodareke@cm.umk.pl (E.G.-K.) \\ 2 Department of Food Hygiene and Consumer Health, Wrocław University of Environmental and Life \\ Sciences, 31 C.K. Norwida St., 50-375 Wrocław, Poland; ewa.walecka@upwr.edu.pl \\ 3 Department of Food Analytics and Environmental Protection, Faculty of Chemical Technology and \\ Engineering, UTP University of Science and Technology, Seminaryjna 3, 85-326 Bydgoszcz, Poland; \\ maria.kowalska@utp.edu.pl \\ 4 Biophysics Department, Faculty of Pharmacy, Collegium Medicum of Nicolaus Copernicus University, \\ Jagiellońska 13-15 St., 85-067 Bydgoszcz, Poland; skrusz@cm.umk.pl \\ * Correspondence: skowron238@wp.pl; Tel.: +48-52-585-3838
}

Received: 30 March 2019; Accepted: 9 May 2019; Published: 10 May 2019

\begin{abstract}
The aim of this study was to compare the biocidal effectiveness of disinfectants solutions prepared with ozonated and non-ozonated water against Listeria monocytogenes. Six L. monocytogenes strains were the research material (four isolates from food: meat (LMO-M), dairy products (LMO-N), vegetables (LMO-W), and fish (LMO-R); one clinical strain (LMO-K) and reference strain ATCC 19111). The evaluation of the biocidal effectiveness of disinfectant solutions (QAC - quaternary ammonium compounds; $\mathrm{OA}$ - oxidizing agents; $\mathrm{ChC}$-chlorine compounds; IC—iodine compounds; NANO-nanoparticles) was carried out, marking the MBC values. Based on the obtained results, the effectiveness coefficient (A) were calculated. The smaller the A value, the greater the efficiency of disinfection solutions prepared on the basis of ozonated versus non-ozonated water. Ozonated water showed biocidal efficacy against L. monocytogenes. Among tested disinfectentants, independent on type of water used for preparation, the most effective against L. monocytogenes were: QAC 1 (benzyl-C12-18-alkydimethyl ammonium chlorides) $\left(1.00 \times 10^{-5}-1.00 \times 10^{-4} \mathrm{~g} / \mathrm{mL}\right)$ in quaternary ammonium compounds, OA 3 (peracetic acid, hydrogen peroxide, bis (sulphate) bis (peroxymonosulfate) $\left(3.08 \times 10^{-4}-3.70 \times 10^{-3} \mathrm{~g} / \mathrm{mL}\right)$ in oxidizing agents, $\mathrm{ChC} 1$ (chlorine dioxide) $\left(5.00 \times 10^{-8}-7.00 \times 10^{-7} \mathrm{~g} / \mathrm{mL}\right)$ in chlorine compounds, IC 1 (iodine) $(1.05-2.15 \mathrm{~g} / \mathrm{mL})$ in iodine compounds, and NANO 1 (nanocopper) $\left(1.08 \times 10^{-4}-1.47 \times 10^{-4} \mathrm{~g} / \mathrm{mL}\right)$ in nanoparticles. The values of the activity coefficient for QAC ranged from 0.10 to 0.40 , for $\mathrm{OA}-0.15-0.84$, for $\mathrm{ChC}-0.25-0.83$, for IC $-0.45-0.60$, and for NANO- $0.70-0.84$. The preparation of disinfectants solution on the basis of ozonated water, improved the microbicidal efficiency of the tested disinfectant, especially the quaternary ammonium compounds. An innovative element of our work is the use of ozonated water for the preparation of working solutions of the disinfection agents. Use ozonated water can help to reduce the use of disinfectant concentrations and limit the increasing of microbial resistance to disinfectants. This paper provides many new information to optimize hygiene plans in food processing plants and limit the spread of microorganisms such as L. monocytogenes.
\end{abstract}


Keywords: Listeria monocytogenes; ozon; ozonated water; non-ozonated water; disinfectants; biocidal effectiveness

\section{Introduction}

Listeria monocytogenes causes listeriosis. This intracellular pathogen is widespread in the environment, from where it can enter the digestive tract of animals and humans [1]. The main source of L. monocytogenes is food, especially smoked fish, cheese, delicatessen meat products, milk, seafood, eggs, and vegetables [2].

Since L. monocytogenes is able to survive under food processing conditions it constitutes a serious threat in food processing plants. To prevent the spread of infection caused by this pathogen, chemical disinfection processes using compounds such as chlorine, iodine, oxidizing, phenolic, quaternary ammonium compounds, alcohols, aldehydes, or metal nanoparticles are carried out [3].

Recently ozone has become an alternative disinfectant. Because of its antibacterial properties, ozone is widely used for the disinfection of drinking water and sewage as well as in the food industry. In the disinfection processes, ozone is used in gaseous or aqueous form depending on the type of decontaminated surfaces. Low concentrations of ozone and short duration of action are sufficient to eliminate microorganisms [4]. It is active against bacteria (such as Listeria spp., Escherichia spp., Salmonella spp.), viruses, fungus, fungal spores, and protozoa [5]. Also, the constant ozonation of water with low ozone concentration $(0.5 \mathrm{mg} / \mathrm{L})$ intended for washing vegetables has resulted in a reduction in the number of mesophilic and coliform bacteria on the surface of lettuce and peppers. This method was less dense in relation to the elimination of mold and fungi. Also the type of vegetable plays a role in the effectiveness of the method (more effective for peppers) [6]. Ozone disturbs the integrity of the bacterial cell membrane by oxidizing phospholipids and lipoproteins. In the case of fungi, ozone inhibits microbial growth in a certain phase. In the case of viruses, ozone damages the viral capsid and interferes with the viral replication cycle [7]. Thanomsub et al. [8], using scanning electron microscopy (SEM), showed deformation of Gram-negative cells exposed to ozone at a concentration of $0.167 / \mathrm{mg} / \mathrm{min} / \mathrm{L}$. After $60 \mathrm{~min}$ exposure, the cells were sunken and concave, while after $90 \mathrm{~min}$ of exposure, they showed lysis. The use of ozone does not require high temperatures and carries many economic benefits [9]. However, its short half-life period is associated with the need to produce it at the place of use. The half-life of ozone in an aqueous solution at $20^{\circ} \mathrm{C}$ is approximately $20-30 \mathrm{~min}$ [10]. The use of ozonated water in the food industry determines the inclusion of organic matter and $\mathrm{pH}$ values. Arayan et al. [11] showed that organic pollution affects the ozone's water half-life, and temperature is also an important factor. An increase in the temperature of ozone water caused a decrease in biocidal effectiveness [11]. Moreover ozone may be corrosive for the treated surface [12]. On the other hand its usage reduces the amount of other disinfectants, and herby the amount of their toxic by-products [4].

The aim of the study was to compare the biocidal effectiveness against L. monocytogenes strains of thirteen selected disinfectants, for which solutions were prepared using sterile hard water and ozone water. The aim was also to assess the stability of solutions of three disinfectants which effectiveness was significantly higher in ozonated water compared to hard water.

\section{Materials and Methods}

\subsection{Bacterial Strains}

The study was conducted on 6 L. monocytogenes strains isolated in 2015 from the territory of the Kuyavian-Pomeranian Voivodeship (Poland), including four isolates from food: meat (LMO-M), dairy products (LMO-N), vegetables (LMO-W), and fish (LMO-R), one clinical strain (LMO-K) from the collection of the Department of Microbiology, Nicolaus Copernicus University in Torun, L. Rydygier Collegium Medicum in Bydgoszcz. These strains were susceptible to all antibiotics tested 
(penicillin, ampicillin, meropenem, erythromycin, cotrimoxazole) in accordance with the EUCAST v.8.00 recommendations [13]. The study material also included the reference strain L. monocytogenes ATCC 19111.

\subsection{Ozonated Water}

In the experiment, the hard water was used, prepared according to the Polish Standard PN-EN 1276: 2010 [14]. A solution A (19.84 $\mathrm{g} \mathrm{MgCl}_{2}$ (Avantor, Gliwice, Poland) and $46.24 \mathrm{~g} \mathrm{CaCl}_{2}$ (Avantor, Gliwice, Poland) was dissolved in $1000 \mathrm{~mL} \mathrm{H}_{2} \mathrm{O}$ ) and $\mathrm{B}\left(35.02 \mathrm{~g} \mathrm{NaHCO}_{3}\right.$ (Avantor, Gliwice, Poland) dissolved in $1000 \mathrm{~mL} \mathrm{H}_{2} \mathrm{O}$ ) was prepared to obtain a hard water. Both solutions were sterilized. Then, $6 \mathrm{~mL}$ of solution $\mathrm{A}$ and $8 \mathrm{~mL}$ of solution $\mathrm{B}$ were added to $700 \mathrm{~mL}$ of sterile water, mixed thoroughly and made up with sterile water to $1000 \mathrm{~mL}$. The ozonation process of $100 \mathrm{~mL}$ of sterile hard water (temperature $20^{\circ} \mathrm{C}, \mathrm{pH}=7.0$ ) was carried out using a 20W ZE-H103 Orientee ozonator (ELTOM, Warsaw, Poland) with a diffuser and with the function of water and air ionization for $45 \mathrm{~min}$. Ozone was generated in a laminar chamber at constant humidity and air temperature. Ozone concentration was determined in the reaction mixtures using DPD ( $N, N$-diethyl-1,4-phenylene diammonium sulfate) Method, according ISO 7393-2:2017 [15], cuvette test and DR3900 Benchtop VIS Spectrophotometer provided by Hach (Frederick, Maryland, USA). This procedure of ozone determination was designed for water samples by Hach company. According to the procedure, the samples are treated with oxidizing agent $\mathrm{N}, \mathrm{N}$-diethyl-1,4-phenylene diammonium sulfate (DPD) to form a red dye. It was determined by visible spectrophotometry $(\lambda \max =552 \mathrm{~nm})$.

Due to the short typical half-life time of ozone in water (15-25 $\mathrm{min}$ for $\mathrm{pH}=7-10)$ [16], ozonated water was immediately used to prepare solutions.

\subsection{Disinfectants}

The study used 13 disinfectants. The composition and concentration (in accordance with the manufacturer's instructions) of working solutions needed to prepare the dilution series are presented in Table 1.

Taking into account the information provided by the manufacturer of a particular disinfector for the preparation of a commercial working solution (100\%), the following solutions were prepared: $200 \%, 180 \%, 160 \%, 140 \%, 120 \%, 100 \%, 80 \%, 60 \%, 40 \%, 20 \%, 10 \%, 2 \%$, and $1 \%$ of working solutions concentrations. The concentrations were selected in order to carry out the procedure for assessing the minimum bactericidal concentrations described in the further part of the methodology. The specific concentrations for particular tested disinfectants were presented in Table 2. Two independent dilution series were prepared—one using sterile hard water [14], the other—sterile ozonated water, immediately after its preparation.

Table 1. Characteristics of disinfectants.

\begin{tabular}{|c|c|c|c|}
\hline Group of Disinfectants & Name & Active Substance & Working Solution Concentration $(\mathrm{g} / \mathrm{mL})$ \\
\hline \multirow{3}{*}{$\begin{array}{l}\text { Quaternary ammonium } \\
\text { compounds }\end{array}$} & QAC 1 & benzyl-C12-18-alkydimethyl ammonium chlorides & $2.0 \times 10^{-3}$ \\
\hline & QAC 2 & benzyl-C12-16 alkyldimethyl chlorides & $2.55 \times 10^{0}$ \\
\hline & QAC 3 & $\begin{array}{l}\text { didecyldimethylammonium chloride, } \\
\text { benzyl-C12-16-alkyldimethyl chlorides }\end{array}$ & $2.97 \times 10^{0}$ \\
\hline \multirow{5}{*}{ Oxidizing agents } & OA 1 & hydrogen peroxide, silver nitrate & $1.20 \times 10^{1}$ \\
\hline & OA 2 & perlactic acid & $4.90 \times 10^{0}$ \\
\hline & OA 3 & peracetic acid, hydrogen peroxide & $6.15 \times 10^{-3}$ \\
\hline & & bis (sulphate) bis (peroxymonosulfate) & \\
\hline & OA 4 & $\begin{array}{l}\text { pentapotassium, benzenesulfonic acid, C10-13 alkyl } \\
\text { derivatives, sodium salts, malic acid, sulfamic acid }\end{array}$ & $2.00 \times 10^{-2}$ \\
\hline \multirow{2}{*}{ Chlorine compounds } & ChC 1 & chlorine dioxide & $1.00 \times 10^{-5}$ \\
\hline & $\mathrm{ChC} 2$ & hypochlorous acid calcium salt & $2.00 \times 10^{-3}$ \\
\hline \multirow{2}{*}{ Iodine compounds } & IC 1 & iodine & $6.15 \times 10^{0}$ \\
\hline & IC 2 & iodine & $1.17 \times 10^{1}$ \\
\hline \multirow{2}{*}{ Nanoparticles } & NANO 1 & nanocopper & $1.50 \times 10^{-4}$ \\
\hline & NANO 2 & nanosilver & $1.50 \times 10^{-4}$ \\
\hline
\end{tabular}


Table 2. The specific concentrations for particular tested disinfectants.

\begin{tabular}{|c|c|c|c|}
\hline Group of Disinfectants & Name & Initial Concentration $(\mathrm{g} / \mathrm{mL})$ & Final Concentration $(\mathrm{g} / \mathrm{mL})$ \\
\hline \multirow[t]{3}{*}{$\begin{array}{l}\text { Quaternary ammonium } \\
\text { compounds }\end{array}$} & QAC 1 & $\begin{array}{c}4.00 \times 10^{-3} ; 3.60 \times 10^{-3} ; 3.20 \times 10^{-3} ; \\
2.80 \times 10^{-3} ; 2.40 \times 10^{-3} ; 2.00 \times 10^{-3} ; \\
1.60 \times 10^{-3} ; 1.20 \times 10^{-3} ; 8.00 \times 10^{-4} ; \\
4.00 \times 10^{-4} ; 2.00 \times 10^{-4} ; 4.00 \times 10^{-5} ; \\
2.00 \times 10^{-5}\end{array}$ & $\begin{array}{l}2.00 \times 10^{-3} ; 1.80 \times 10^{-3} ; 1.60 \times 10^{-3} ; \\
1.40 \times 10^{-3} ; 1.20 \times 10^{-3} ; 1.00 \times 10^{-3} ; \\
8.00 \times 10^{-4} ; 6.00 \times 10^{-4} ; 4.00 \times 10^{-4} ; \\
2.00 \times 10^{-4} ; 1.00 \times 10^{-4} ; 2.00 \times 10^{-5} ; \\
1.00 \times 10^{-5}\end{array}$ \\
\hline & QAC 2 & $\begin{array}{c}5.1 \times 10^{0} ; 4.59 \times 10^{0} ; 4.08 \times 10^{0} ; 3.57 \times \\
10^{0} ; 3.06 \times 10^{0} ; 2.55 \times 10^{0} ; 2.04 \times 10^{0} ; \\
1.53 \times 10^{0} ; 1.02 \times 10^{0} ; 5.1 \times 10^{-1} ; 2.6 \times \\
10^{-1} ; 5.00 \times 10^{-2} ; 2.6 \times 10^{-2}\end{array}$ & $\begin{array}{c}2.55 \times 10^{0} ; 2.30 \times 10^{0} ; 2.04 \times 10^{0} ; 1.79 \times \\
10^{0} ; 1.53 \times 10^{0} ; 1.28 \times 10^{0} ; 1.02 \times 10^{0} ; \\
7.70 \times 10^{-1} ; 5.10 \times 10^{-1} ; 2.60 \times 10^{-1} ; \\
1.30 \times 10^{-1} ; 2.60 \times 10^{-2} ; 1.00 \times 10^{-2}\end{array}$ \\
\hline & QAC 3 & $\begin{array}{l}5.94 \times 10^{0} ; 5.35 \times 10^{0} ; 4.75 \times 10^{0} ; 4.16 \times \\
10^{0} ; 3.56 \times 10^{0} ; 2.97 \times 10^{0} ; 2.38 \times 10^{0} ; \\
1.78 \times 10^{0} ; 1.19 \times 10^{0} ; 5.90 \times 10^{-1} ; 3.00 \\
\quad \times 10^{-1} ; 5.90 \times 10^{-2} ; 3.00 \times 10^{-2}\end{array}$ & $\begin{array}{r}2.97 \times 10^{0} ; 2.67 \times 10^{0} ; 2.38 \times 10^{0} ; 2.08 \times \\
10^{0} ; 1.78 \times 10^{0} ; 1.49 \times 10^{0} ; 1.19 \times 10^{0} ; \\
8.90 \times 10^{-1} ; 5.90 \times 10^{-1} ; 2.30 \times 10^{-1} ; \\
1.50 \times 10^{-1} ; 3.00 \times 10^{-2} ; 1.50 \times 10^{-2}\end{array}$ \\
\hline \multirow[t]{4}{*}{ Oxidizing agents } & OA 1 & $\begin{array}{l}2.40 \times 10^{1} ; 2.16 \times 10^{1} ; 1.92 \times 10^{1} ; 1.68 \times \\
10^{1} ; 1.44 \times 10^{1} ; 1.20 \times 10^{1}, 9.60 \times 10^{0} ; \\
7.20 \times 10^{0} ; 4.80 \times 10^{0} ; 2.40 \times 10^{0} ; 1.20 \times \\
10^{0} ; 2.40 \times 10^{-1} ; 1.20 \times 10^{-1}\end{array}$ & $\begin{array}{l}1.20 \times 10^{1} ; 1.08 \times 10^{1} ; 9.60 \times 10^{0} ; 8.40 \times \\
10^{0} ; 7.20 \times 10^{0} ; 6.00 \times 10^{0} ; 4.80 \times 10^{0} ; \\
3.60 \times 10^{0} ; 2.40 \times 10^{0} ; 1.20 \times 10^{0} ; 6.00 \times \\
10^{-1} ; 1.20 \times 10^{-1} ; 6.00 \times 10^{-2}\end{array}$ \\
\hline & OA 2 & $\begin{array}{l}9.80 \times 10^{0} ; 8.82 \times 10^{0} ; 7.84 \times 10^{0} ; 6.86 \times \\
10^{0} ; 5.88 \times 10^{0}, 4.90 \times 10^{0} ; 3.92 \times 10^{0} ; \\
2.94 \times 10^{0} ; 1.96 \times 10^{0} ; 9.80 \times 10^{-1} ; 4.90 \\
\quad \times 10^{-1} ; 9.80 \times 10^{-2} ; 4.90 \times 10^{-2}\end{array}$ & $\begin{array}{l}4.90 \times 10^{0} ; 4.41 \times 10^{0} ; 3.92 \times 10^{0} ; 3.43 \times \\
10^{0} ; 2.45 \times 10^{0} ; 2.40 \times 10^{0} ; 1.96 \times 10^{0} ; \\
1.47 \times 10^{0} ; 9.80 \times 10^{-1} ; 4.90 \times 10^{-1} ; 2.50 \\
\quad \times 10^{-1} ; 5.00 \times 10^{-2} ; 2.50 \times 10^{-2}\end{array}$ \\
\hline & OA 3 & $\begin{array}{c}1.20 \times 10^{-2} ; 1.00 \times 10^{-2} ; 9.80 \times 10^{-3} ; \\
8.60 \times 10^{-3} ; 7.40 \times 10^{-3} ; 6.15 \times 10^{-3} ; \\
4.92 \times 10^{-3} ; 3.69 \times 10^{-3} ; 2.46 \times 10^{-3} ; \\
1.23 \times 10^{-3} ; 6.15 \times 10^{-4} ; 1.23 \times 10^{-4} ; \\
\quad 6.15 \times 10^{-5}\end{array}$ & $\begin{array}{c}6.15 \times 10^{-3} ; 5.50 \times 10^{-3} ; 4.90 \times 10^{-3} ; \\
4.30 \times 10^{-3} ; 3.70 \times 10^{-3} ; 3.10 \times 10^{-3} ; \\
2.46 \times 10^{-3} ; 1.90 \times 10^{-3} ; 1.23 \times 10^{-3} ; \\
6.15 \times 10^{-4} ; 3.10 \times 10^{-4} ; 6.15 \times 10^{-5} ; \\
\quad 3.10 \times 10^{-5}\end{array}$ \\
\hline & OA 4 & $\begin{array}{c}4.00 \times 10^{-2} ; 3.60 \times 10^{-2} ; 3.20 \times 10^{-2} ; \\
2.80 \times 10^{-2} ; 2.40 \times 10^{-2} ; 2.00 \times 10^{-2} ; \\
1.60 \times 10^{-2} ; 1.20 \times 10^{-2} ; 8.00 \times 10^{-3} ; \\
4.00 \times 10^{-3} ; 2.00 \times 10^{-3} ; 4.00 \times 10^{-4} ; \\
2.00 \times 10^{-4}\end{array}$ & $\begin{array}{c}2.00 \times 10^{-2} ; 1.80 \times 10^{-2} ; 1.60 \times 10^{-2} ; \\
1.40 \times 10^{-2} ; 1.20 \times 10^{-2} ; 1.00 \times 10^{-2} ; \\
8.00 \times 10^{-3} ; 6.00 \times 10^{-3} ; 4.00 \times 10^{-3} ; \\
2.00 \times 10^{-3} ; 1.00 \times 10^{-3} ; 2.00 \times 10^{-4} ; \\
1.00 \times 10^{-4}\end{array}$ \\
\hline \multirow[t]{2}{*}{ Chlorine compounds } & ChC 1 & $\begin{array}{c}2.00 \times 10^{-5} ; 1.8 \times 10^{-5} ; 1.6 \times 10^{-5} ; 1.4 \times \\
10^{-5} ; 1.20 \times 10^{-5} ; 1.00 \times 10^{-5} ; 8.00 \times \\
10^{-6} ; 6.00 \times 10^{-6} ; 4.00 \times 10^{-6} ; 2.00 \times \\
10^{-6} ; 1.00 \times 10^{-6} ; 2.00 \times 10^{-7} ; 1.00 \times \\
10^{-7}\end{array}$ & $\begin{array}{l}1.00 \times 10^{-5} ; 9.00 \times 10^{-6} ; 8.00 \times 10^{-6} ; \\
7.00 \times 10^{-6} ; 6.00 \times 10^{-6} ; 5.00 \times 10^{-6} ; \\
4.00 \times 10^{-6} ; 3.00 \times 10^{-6} ; 2.00 \times 10^{-6} ; \\
1.00 \times 10^{-6} ; 2.00 \times 10^{-7} ; 1.00 \times 10^{-7}\end{array}$ \\
\hline & $\mathrm{ChC} 2$ & $\begin{array}{r}4.00 \times 10^{-3} ; 3.60 \times 10^{-3} ; 3.20 \times 10^{-3} ; \\
2.80 \times 10^{-3} ; 2.40 \times 10^{-3} ; 2.00 \times 10^{-3} ; \\
1.60 \times 10^{-3} ; 1.20 \times 10^{-3} ; 8.00 \times 10^{-4} ; \\
4.00 \times 10^{-4} ; 2.00 \times 10^{-4} ; 4.00 \times 10^{-5} ; \\
\quad 2.00 \times 10^{-5}\end{array}$ & $\begin{array}{r}2.00 \times 10^{-3} ; 1.80 \times 10^{-3} ; 1.60 \times 10^{-3} ; \\
1.40 \times 10^{-3} ; 1.20 \times 10^{-3} ; 1.00 \times 10^{-3} ; \\
8.00 \times 10^{-4} ; 6.00 \times 10^{-4} ; 4.00 \times 10^{-4} ; \\
2.00 \times 10^{-4} ; 1.00 \times 10^{-4} ; 2.00 \times 10^{-5} ; \\
1.00 \times 10^{-5}\end{array}$ \\
\hline \multirow[t]{2}{*}{ Iodine compounds } & IC 1 & $\begin{array}{c}1.23 \times 10^{1} ; 1.11 \times 10^{1} ; 9.84 \times 10^{0} ; 8.61 \times \\
10^{0} ; 7.38 \times 10^{0} ; 6.15 \times 10^{0} ; 4.92 \times 10^{0} ; \\
3.69 \times 10^{0} ; 2.46 \times 10^{0} ; 1.23 \times 10^{0} ; 6.20 \times \\
10^{-1} ; 1.20 \times 10^{-1} ; 6.20 \times 10^{-2}\end{array}$ & $\begin{array}{l}6.15 \times 10^{0} ; 5.54 \times 10^{0} ; 4.92 \times 10^{0} ; 4.31 \times \\
10^{0} ; 3.69 \times 10^{0} ; 3.08 \times 10^{0} ; 2.46 \times 10^{0} ; \\
1.85 \times 10^{0} ; 1.23 \times 10^{0} ; 6.20 \times 10^{-1} ; 3.10 \\
\quad \times 10^{-1} ; 6.20 \times 10^{-2} ; 3.10 \times 10^{-2}\end{array}$ \\
\hline & IC 2 & $\begin{array}{c}2.34 \times 10^{1} ; 2.11 \times 10^{1} ; 1.87 \times 10^{1} ; 1.64 \times \\
10^{1} ; 1.40 \times 10^{1} ; 1.17 \times 10^{1} ; 9.36 \times 10^{0} ; \\
7.02 \times 10^{0} ; 4.68 \times 10^{0} ; 2.34 \times 10^{0} ; 1.17 \times \\
10^{0} ; 2.30 \times 10^{-1} ; 1.20 \times 10^{-1}\end{array}$ & $\begin{array}{l}1.17 \times 10^{1} ; 1.05 \times 10^{1} ; 9.36 \times 10^{0} ; 8.19 \times \\
10^{0} ; 7.02 \times 10^{0} ; 5.85 \times 10^{0} ; 4.68 \times 10^{0} ; \\
3.51 \times 10^{0} ; 2.34 \times 10^{0} ; 1.17 \times 10^{0} ; 5.90 \times \\
10^{-1} ; 1.20 \times 10^{-1} ; 5.90 \times 10^{-2}\end{array}$ \\
\hline \multirow[t]{2}{*}{ Nanoparticles } & NANO 1 & $\begin{array}{l}3.00 \times 10^{-3} ; 2.70 \times 10^{-3} ; 2.40 \times 10^{-3} ; \\
2.10 \times 10^{-3} ; 1.80 \times 10^{-3} ; 1.50 \times 10^{-3} ; \\
1.20 \times 10^{-3} ; 9.00 \times 10^{-4} ; 6.00 \times 10^{-4} ; \\
3.00 \times 10^{-4} ; 1.50 \times 10^{-4} ; 3.00 \times 10^{-5} ; \\
1.50 \times 10^{-5}\end{array}$ & $\begin{array}{r}1.50 \times 10^{-4} ; 1.35 \times 10^{-4} ; 1.20 \times 10^{-4} ; \\
1.05 \times 10^{-4} ; 9.00 \times 10^{-5} ; 7.50 \times 10^{-5} ; \\
6.00 \times 10^{-5} ; 4.50 \times 10^{-5} ; 3.00 \times 10^{-5} ; \\
1.50 \times 10^{-5} ; 7.50 \times 10^{-6} ; 1,50 \times 10^{-6} ; \\
7.50 \times 10^{-7}\end{array}$ \\
\hline & NANO 2 & $\begin{array}{r}3.00 \times 10^{-3} ; 2.70 \times 10^{-3} ; 2.40 \times 10^{-3} \\
2.10 \times 10^{-3} ; 1.80 \times 10^{-3} ; 1.50 \times 10^{-3} ; \\
1.20 \times 10^{-3} ; 9.00 \times 10^{-4} ; 6.00 \times 10^{-4} ; \\
3.00 \times 10^{-4} ; 1.50 \times 10^{-4} ; 3.00 \times 10^{-5} \\
\quad 1.50 \times 10^{-5}\end{array}$ & $\begin{array}{r}1.50 \times 10^{-4} ; 1.35 \times 10^{-4} ; 1.20 \times 10^{-4} ; \\
1.05 \times 10^{-4} ; 9.00 \times 10^{-5} ; 7.50 \times 10^{-5} ; \\
6.00 \times 10^{-5} ; 4.50 \times 10^{-5} ; 3.00 \times 10^{-5} ; \\
1.50 \times 10^{-5} ; 7.50 \times 10^{-6} ; 1,50 \times 10^{-6} ; \\
7.50 \times 10^{-7}\end{array}$ \\
\hline
\end{tabular}

QAC 1-benzyl-C12-18-alkydimethyl ammonium chlorides; QAC 2-benzyl-C12-16 alkyldimethyl chlorides; QAC 3-didecyldimethylammonium chloride, benzyl-C12-16-alkyldimethyl chlorides; OA 1-hydrogen peroxide, silver nitrate; OA 2-perlactic acid; OA 3-peracetic acid, hydrogen peroxide bis (sulphate) bis (peroxymonosulfate); OA 4-pentapotassium, benzenesulfonic acid, C10-13 alkyl derivatives, sodium salts, malic acid, sulfamic acid; ChC 1-chlorine dioxide; ChC 2-hypochlorous acid calcium salt; IC 1-iodine, IC 2-iodine; NANO 1-nanocopper; NANO 2-nanosilver. 


\subsection{Preparation of Bacterial Supensions}

From cultures of L. monocytogenes strains obtained on Columbia Agar with 5\% sheep blood (CAB, bioMérieux, Marcy-l'Étoile, France) suspensions of a density of 0.5 MacFarland standard $\left(5.80 \times 10^{8}\right.$ $\mathrm{CFU} \times \mathrm{mL}^{-1}$ ) were prepared in $3 \mathrm{~mL}$ of Mueller Hinton Broth (MHB, Becton Dickinson, Franklin Lakes, New Jersey, USA). For this purpose, the optical density for the sterile MHB (Mueller Hinton Broth, Becton Dickinson, Franklin Lakes, New Jersey, USA) medium was first established. A sterile swab was then collected from a single colony grown on Columbia Agar with $5 \%$ sheep blood (CAB, bioMérieux, Marcy-l'Étoile, France) and loaded into the MHB (Mueller Hinton Broth, Becton Dickinson, Franklin Lakes, New Jersey, USA) medium, followed by measurement of the optical density of the suspension and subsequent colonization of L. monocytogenes added if necessary. The optical density of the suspension was set at 0.5 + the optical density of the sterile MHB (Mueller Hinton Broth, Becton Dickinson, Franklin Lakes, New Jersey, USA). The measurements were made with a DEN-1B denitometer from Biogenet (Józefów, Poland).

\subsection{Assessment of Biocidal Effectiveness of Ozonated and Non-Ozonated Water}

The suspensions of the tested L. monocytogenes strains $(100 \mu \mathrm{L})$ were pipetted into Eppendorf ( $1.5 \mathrm{~mL}$, Genoplast, Poland) tubes. After centrifugation ( $3000 \mathrm{rpm}$ per $5 \mathrm{~min}$ ) of the bacterial suspensions, $150 \mu \mathrm{L}$ of an ozone solution of appropriate concentration (the mean value determined according to point 2.2-2.32 $\mu \mathrm{g} \mathrm{O}_{3} / \mathrm{mL}$ ) was added to the sediments. Immediately after preparation of the suspension in ozonated/non-ozonated water, a row of decimal dilutions were made in sterile PBS (Phosphate-buffered saline, Avantor, Gliwice, Poland). Each dilution $(100 \mu \mathrm{L})$ was seeded into a Columbia Agar with 5\% sheep blood ( $\mathrm{CAB}$, bioMérieux, Marcy-1'Étoile, France) and incubated for $24 \mathrm{~h}$ at $37^{\circ} \mathrm{C}$. In this way, the initial number of $L$. monocytogenes was determined. The number of bacteria in the obtained suspension was 3.60-4.20 $\times 10^{8} \mathrm{CFU} \times \mathrm{mL}^{-1}$. The negative control was $150 \mu \mathrm{L}$ of ozon water, and the positive control $-150 \mu \mathrm{L}$ of bacterial suspension of a given strain suspended in sterile hard water. The study was carried out in triplicate for each strain and each tested concentration.

After $5 \mathrm{~min}$ of treatment of the suspensions with ozonated water, sample were transferred to $900 \mu \mathrm{L}$ neutralizer (10 g Tween 80 (Sigma Aldrich, Saint Louis, Missouri, USA), $1 \mathrm{~g}$ lecithin (Sigma Aldrich, Saint Louis, Missouri, USA), $0.5 \mathrm{~g}$ histidine L (Sigma Aldrich, Saint Louis, Missouri, USA), $2.5 \mathrm{~g} \mathrm{Na}_{2} \mathrm{~S}_{2} \mathrm{O}_{3}$ (Avantor, Gliwice, Poland), $3.5 \mathrm{~g} \mathrm{C}_{3} \mathrm{H}_{3} \mathrm{NaO}_{3}$ (Avantor, Gliwice, Poland), $1000 \mathrm{~mL}$ sterile water). Lecithin neutralizes quaternary ammonia compounds while phenolic disinfectants and hexachlorophene are neutralized by Tween. Together, lecithin and Tween neutralize ethanol. Histidine inactivates aldehydes, especially formaldehyde and gluteraldehyde. Sodium thiosulfate neutralizes iodine and chlorine, whereas sodium pyruvate neutralizes active oxygen and peroxides $[17,18]$. After 5 min of exposure, linear cultures were made on the CAB (Columbia Agar with 5\% sheep blood, bioMérieux, Marcy-l'Étoile, France) substrate plate sectors that were incubated for $24 \mathrm{~h}$ at $37^{\circ} \mathrm{C}$. After incubation, the concentration of ozonated water was analyzed, which enabled the inactivation of the tested strains of L. monocytogenes. The effect of sterile hard water [15] on the number of recovered bacteria was also assessed.

After determining the concentration range in which the value of the minimum bactericidal concentration $(\mathrm{MBC})$ of ozonated water was located, the procedure was repeated, preparing solutions with a concentration varying by $1 \%$ in this range, in order to accurately determine the MBC (minimum bactericidal concentration).

To check the durability of ozonated water, the same test cycle was carried out one and two $h$ after the ozonation process was completed. All plates with banded cultures were incubated under the conditions described above, and then the results were read. 


\subsection{Evaluation of the Effectiveness of Disinfectants}

The suspensions of the tested strains of L. monocytogenes $(100 \mu \mathrm{L})$ and $100 \mu \mathrm{L}$ of the appropriate concentration of disinfectant were introduced into the wells of a multi-well polystyrene plate. The target concentration of the disinfectant in the well plate was respectively $100 \%, 90 \%, 80 \%, 70 \%, 60 \%$, $50 \%, 40 \%, 30 \%, 20 \%, 10 \%, 5 \%, 1 \%$, and $0.5 \%$ concentration working solution of a particular disinfectant. The specific concentrations for particular tested disinfectants were presented in Table 2. The negative control consisted of $200 \mu \mathrm{L}$ of sterile MHB (Mueller Hinton Broth, Becton Dickinson, Franklin Lakes, New Jersey, USA) medium, and a positive control-200 $\mu \mathrm{L}$ of bacterial suspension. After 5 min of the agent's action on bacterial suspensions, $100 \mu \mathrm{L}$ of liquid was transferred from each well to $900 \mu \mathrm{L}$ of neutralizer. After 5 min of neutralization, band-cultures were made on the CAB (Columbia Agar with 5\% sheep blood, bioMérieux, Marcy-l'Étoile, France) segments, which were incubated for $24 \mathrm{~h}$ at $37^{\circ} \mathrm{C}$. After incubation, the minimum concentration allowing inactivation of the tested strains of L. monocytogenes was read for solutions based on non-ozonated and ozonated water.

After determining the concentration range in which the value of the minimum bactericidal concentration (MBC) of a given disinfectant was located, the procedure was repeated by preparing solutions with a concentration varying by $1 \%$ in this range, to accurately determine the MBC.

Based on the obtained results, for all strains and disinfectants used in the studies, the effectiveness coefficient (A) were calculated [19]. The smaller the value of the coefficient A, the greater the efficiency of disinfecting solutions based on ozonated water compared to non-ozonated disinfectants.

The effectiveness factor was calculated from the formula:

$$
\mathrm{A}=\mathrm{b} / \mathrm{c}
$$

where:

A-effectiveness coefficient,

$\mathrm{b}$-effective concentration of disinfectant in active solution (ozonated water),

c-effective concentration of disinfectant in non-ozonated water solution.

In order to assess the decrease in the number of L. monocytogenes under the influence of disinfectants prepared on the basis of ozonated and non-ozonated water, the initial number of tested bacteria and the number of bacteria isolated at preMBC disinfectant concentration were determined. For this purpose, a series of decimal dilutions was made for the prepared suspension of a given strain and then plated on CAB (Columbia Agar with 5\% sheep blood, bioMérieux, Marcy-l'Étoile, France) agar. The cultures were incubated at $37^{\circ} \mathrm{C}$ for $24 \mathrm{~h}$. After this time, the grown colonies were counted and converted into logarithmic units. Similarly, the suspension subjected to action of the disinfectant concentration directly preceding $\mathrm{MBC}$ (preMBC) was treated. To determine preMBC, the MBC value from Table 3 was checked and the directly preceding concentration was selected from Table 2 . The decreases in the number of bacteria were calculated from the formula:

$$
\mathrm{R}=\log _{\mathrm{i}}-\log _{\mathrm{preMBC}}
$$

where:

$\mathrm{R}$-reduction in bacteria number (log CFU)

$\log _{\mathrm{i}}$-initial bacteria number

$\log _{\text {preMBC }}$-nuber of bacteria recovered from suspension trated with preMBC concentration of disinfectant 
Table 3. Minimal bactericidal concentration of tested disinfectant depending of water type $(\mathrm{g} / \mathrm{mL})$.

\begin{tabular}{|c|c|c|c|c|c|c|c|c|}
\hline \multirow{3}{*}{$\begin{array}{c}\text { Group of } \\
\text { Disinfectants }\end{array}$} & \multirow{3}{*}{ Disinfectant } & \multirow{3}{*}{ Water Type } & \multicolumn{6}{|c|}{ Minimal Bactericidal Concentration of Disinfectant $(\mathrm{g} / \mathrm{mL})$} \\
\hline & & & & & & & & \\
\hline & & & LMO-ATCC & LMO-W & LMO-M & LMO-N & LMO-R & LMO-K \\
\hline \multirow{3}{*}{$\begin{array}{l}\text { Quaternary } \\
\text { ammonium } \\
\text { compounds }\end{array}$} & QAC 1 & $\begin{array}{c}\text { Nonozonated } \\
\text { Ozonated }\end{array}$ & $\begin{array}{l}1.00 \times 10^{-4 a} \mathrm{a} \\
4.00 \times 10^{-5} \mathrm{~b}\end{array}$ & $\begin{array}{l}1.00 \times 10^{-4 a} \mathrm{a} \\
2.00 \times 10^{-5} \mathrm{~b}\end{array}$ & $\begin{array}{l}4.00 \times 10^{-5 b} \\
1.00 \times 10^{-5 b}\end{array}$ & $\begin{array}{l}4.00 \times 10^{-5 b} \\
1.00 \times 10^{-5 b}\end{array}$ & $\begin{array}{l}4.00 \times 10^{-5 b} \\
1.00 \times 10^{-5 b}\end{array}$ & $\begin{array}{l}1.00 \times 10^{-4 a} \\
4.00 \times 10^{-5} \mathrm{~b}\end{array}$ \\
\hline & QAC 2 & $\begin{array}{c}\text { Nonozonated } \\
\text { Ozonated }\end{array}$ & $\begin{array}{l}1.28 \times 10^{-1 c} \mathrm{c} \\
1.28 \times 10^{-2 \mathrm{~d}}\end{array}$ & $\begin{array}{l}1.28 \times 10^{-1 c} \mathrm{c} \\
1.28 \times 10^{-2 \mathrm{~d}}\end{array}$ & $\begin{array}{l}1.28 \times 10^{-1 \mathrm{c}} \\
1.28 \times 10^{-2 \mathrm{~d}}\end{array}$ & $\begin{array}{l}1.28 \times 10^{-1 \mathrm{c}} \\
1.28 \times 10^{-2 \mathrm{~d}}\end{array}$ & $\begin{array}{l}1.28 \times 10^{-1 \mathrm{c}} \\
1.28 \times 10^{-2 \mathrm{~d}}\end{array}$ & $\begin{array}{l}1.28 \times 10^{-1 \mathrm{c}} \\
1.28 \times 10^{-2 \mathrm{~d}}\end{array}$ \\
\hline & QAC 3 & $\begin{array}{c}\text { Nonozonated } \\
\text { Ozonated }\end{array}$ & $\begin{array}{l}1.49 \times 10^{-1 c} \mathrm{c} \\
1.49 \times 10^{-2 \mathrm{~d}}\end{array}$ & $\begin{array}{l}1.49 \times 10^{-1 c} \mathrm{c} \\
2.97 \times 10^{-2 \mathrm{~d}}\end{array}$ & $\begin{array}{l}1.49 \times 10^{-1 \mathrm{c}} \\
1.49 \times 10^{-2 \mathrm{~d}}\end{array}$ & $\begin{array}{l}1.49 \times 10^{-1 \mathrm{c}} \\
1.49 \times 10^{-2 \mathrm{~d}}\end{array}$ & $\begin{array}{l}1.49 \times 10^{-1 c} \mathrm{c} \\
1.49 \times 10^{-2 \mathrm{~d}}\end{array}$ & $\begin{array}{l}1.49 \times 10^{-1 \mathrm{c}} \\
1.49 \times 10^{-2 \mathrm{~d}}\end{array}$ \\
\hline \multirow{4}{*}{ Oxidizing agents } & OA 1 & $\begin{array}{l}\text { Nonozonated } \\
\text { Ozonated }\end{array}$ & $\begin{array}{l}1.20 \times 10^{1 \mathrm{e}} \\
1.01 \times 10^{1 \mathrm{e}}\end{array}$ & $\begin{array}{l}1.20 \times 10^{1 \mathrm{e}} \\
1.01 \times 10^{1 \mathrm{e}}\end{array}$ & $\begin{array}{l}1.20 \times 10^{1 \mathrm{e}} \\
1.01 \times 10^{1 \mathrm{e}}\end{array}$ & $\begin{array}{l}1.20 \times 10^{1 \mathrm{e}} \\
1.01 \times 10^{1 \mathrm{e}}\end{array}$ & $\begin{array}{l}1.20 \times 10^{1 \mathrm{e}} \\
1.01 \times 10^{1 \mathrm{e}}\end{array}$ & $\begin{array}{l}1.20 \times 10^{1 \mathrm{e}} \\
1.01 \times 10^{1 \mathrm{e}}\end{array}$ \\
\hline & OA 2 & $\begin{array}{c}\text { Nonozonated } \\
\text { Ozonated }\end{array}$ & $\begin{array}{l}4.90 \times 10^{0 \mathrm{k}} \\
2.70 \times 10^{0 \mathrm{f}}\end{array}$ & $\begin{array}{l}\text { Ineffective } \\
2.79 \times 10^{0 \mathrm{f}}\end{array}$ & $\begin{array}{c}\text { Ineffective } \\
3.38 \times 10^{0 \mathrm{ft}, \mathrm{k}}\end{array}$ & $\begin{array}{l}4.90 \times 10^{0 \mathrm{k}} \\
2.70 \times 10^{0 \mathrm{f}}\end{array}$ & $\begin{array}{c}\text { Ineffective } \\
3.68 \times 10^{0 \mathrm{f,k}}\end{array}$ & $\begin{array}{l}4.90 \times 10^{0 \mathrm{k}} \\
2.70 \times 10^{0 \mathrm{f}}\end{array}$ \\
\hline & $\mathrm{OA} 3$ & $\begin{array}{c}\text { Nonozonated } \\
\text { Ozonated }\end{array}$ & $\begin{array}{l}1.42 \times 10^{-3} \mathrm{~g} \\
3.08 \times 10^{-4 a}\end{array}$ & $\begin{array}{l}1.42 \times 10^{-3} \mathrm{~g} \\
3.08 \times 10^{-4 \mathrm{a}}\end{array}$ & $\begin{array}{l}1.85 \times 10^{-3} \mathrm{~g} \\
4.31 \times 10^{-4 a}\end{array}$ & $\begin{array}{l}1.85 \times 10^{-3} \mathrm{~g} \\
3.08 \times 10^{-4 a}\end{array}$ & $\begin{array}{l}3.69 \times 10^{-3} \mathrm{~g} \\
5.54 \times 10^{-4} \mathrm{a}\end{array}$ & $\begin{array}{l}1.42 \times 10^{-3} \mathrm{~g} \\
3.08 \times 10^{-4} \mathrm{a}\end{array}$ \\
\hline & OA 4 & $\begin{array}{l}\text { Nonozonated } \\
\text { Ozonated }\end{array}$ & $\begin{array}{l}4.20 \times 10^{-3 \mathrm{~h}} \\
1.60 \times 10^{-3} \mathrm{~g}\end{array}$ & $\begin{array}{l}4.20 \times 10^{-3 \mathrm{~h}} \\
1.60 \times 10^{-3} \mathrm{~g}\end{array}$ & $\begin{array}{l}4.20 \times 10^{-3 \mathrm{~h}} \\
1.60 \times 10^{-3} \mathrm{~g}\end{array}$ & $\begin{array}{l}4.20 \times 10^{-3 \mathrm{~h}} \\
1.60 \times 10^{-3} \mathrm{~g}\end{array}$ & $\begin{array}{l}4.20 \times 10^{-3 \mathrm{~h}} \\
1.60 \times 10^{-3} \mathrm{~g}\end{array}$ & $\begin{array}{l}4.20 \times 10^{-3 \mathrm{~h}} \\
1.60 \times 10^{-3} \mathrm{~g}\end{array}$ \\
\hline \multirow[t]{2}{*}{ Chlorine compounds } & $\mathrm{ChC} 1$ & $\begin{array}{l}\text { Nonozonated } \\
\text { Ozonated }\end{array}$ & $\begin{array}{l}2.00 \times 10^{-7 i} \\
5.00 \times 10^{-8 j}\end{array}$ & $\begin{array}{l}4.00 \times 10^{-7 i} \\
1.00 \times 10^{-7 i}\end{array}$ & $\begin{array}{l}7.00 \times 10^{-7 i} \\
3.00 \times 10^{-7 i}\end{array}$ & $\begin{array}{l}4.00 \times 10^{-7 i} \\
1.00 \times 10^{-7 i}\end{array}$ & $\begin{array}{l}6.00 \times 10^{-7 i} \\
2.00 \times 10^{-7 i}\end{array}$ & $\begin{array}{l}4.00 \times 10^{-7 i} \\
1.00 \times 10^{-7 i}\end{array}$ \\
\hline & $\mathrm{ChC} 2$ & $\begin{array}{c}\text { Nonozonated } \\
\text { Ozonated }\end{array}$ & $\begin{array}{l}2.40 \times 10^{-1 \mathrm{c}} \\
2.00 \times 10^{-1 \mathrm{c}}\end{array}$ & $\begin{array}{l}3.20 \times 10^{-1 \mathrm{c}} \\
2.00 \times 10^{-1 \mathrm{c}}\end{array}$ & $\begin{array}{l}3.60 \times 10^{-1 \mathrm{c}} \\
2.00 \times 10^{-1 \mathrm{c}}\end{array}$ & $\begin{array}{l}3.20 \times 10^{-1 c} \mathrm{c} \\
2.00 \times 10^{-1 c} \\
\end{array}$ & $\begin{array}{l}2.80 \times 10^{-1 \mathrm{c}} \\
2.00 \times 10^{-1 \mathrm{c}} \\
\end{array}$ & $\begin{array}{c}4.0 \times 10^{-1} \mathrm{c} \\
2.80 \times 10^{-1 \mathrm{c}}\end{array}$ \\
\hline \multirow{2}{*}{ Iodine compounds } & IC 1 & $\begin{array}{l}\text { Nonozonated } \\
\text { Ozonated }\end{array}$ & $\begin{array}{l}2.15 \times 10^{0 \mathrm{f}} \\
1.05 \times 10^{01}\end{array}$ & $\begin{array}{l}2.15 \times 10^{0 \mathrm{f}} \\
1.29 \times 10^{01}\end{array}$ & $\begin{array}{l}2.15 \times 10^{0 \mathrm{f}} \\
1.29 \times 10^{01}\end{array}$ & $\begin{array}{l}2.15 \times 10^{0 \mathrm{f}} \\
1.29 \times 10^{01}\end{array}$ & $\begin{array}{l}2.15 \times 10^{0 \mathrm{f}} \\
1.29 \times 10^{01}\end{array}$ & $\begin{array}{l}2.15 \times 10^{0 \mathrm{f}} \\
1.05 \times 10^{01}\end{array}$ \\
\hline & IC 2 & $\begin{array}{l}\text { Nonozonated } \\
\text { Ozonated }\end{array}$ & $\begin{array}{c}3.63 \times 10^{0 \mathrm{f}, \mathrm{k}} \\
1.64 \times 10^{01}\end{array}$ & $\begin{array}{c}3.63 \times 10^{0 \mathrm{f}, \mathrm{k}} \\
1.64 \times 10^{01}\end{array}$ & $\begin{array}{c}3.86 \times 10^{0 \mathrm{f}, \mathrm{k}} \\
1.76 \times 10^{01}\end{array}$ & $\begin{array}{c}3.63 \times 10^{0 \mathrm{f}, \mathrm{k}} \\
1.64 \times 10^{01}\end{array}$ & $\begin{array}{c}3.63 \times 10^{0 \mathrm{f}, \mathrm{k}} \\
1.69 \times 10^{01}\end{array}$ & $\begin{array}{c}3.86 \times 10^{0 \mathrm{f}, \mathrm{k}} \\
1.76 \times 10^{01}\end{array}$ \\
\hline \multirow{2}{*}{ Nanoparticles } & NANO 1 & $\begin{array}{l}\text { Nonozonated } \\
\text { Ozonated }\end{array}$ & $\begin{array}{l}1.37 \times 10^{-4 a} \\
1.08 \times 10^{-4} \mathrm{a}\end{array}$ & $\begin{array}{l}1.37 \times 10^{-4 \mathrm{a}} \\
1.14 \times 10^{-4} \mathrm{a}\end{array}$ & $\begin{array}{l}1.41 \times 10^{-4 a} \mathrm{a} \\
1.14 \times 10^{-4} \mathrm{a}\end{array}$ & $\begin{array}{l}1.37 \times 10^{-4 a} \\
1.08 \times 10^{-4} \mathrm{a}\end{array}$ & $\begin{array}{l}1.47 \times 10^{-4 a} \mathrm{a} \\
1.19 \times 10^{-4} \mathrm{a}\end{array}$ & $\begin{array}{l}1.37 \times 10^{-4 a} \mathrm{a} \\
1.08 \times 10^{-4} \mathrm{a}\end{array}$ \\
\hline & NANO 2 & $\begin{array}{c}\text { Nonozonated } \\
\text { Ozonated }\end{array}$ & $\begin{array}{c}\text { Ineffective } \\
1.20 \times 10^{-4} \mathrm{a}\end{array}$ & $\begin{array}{c}\text { Ineffective } \\
1.20 \times 10^{-4} \mathrm{a}\end{array}$ & $\begin{array}{c}\text { Ineffective } \\
1.20 \times 10^{-4} \mathrm{a}\end{array}$ & $\begin{array}{c}\text { Ineffective } \\
1.20 \times 10^{-4} \mathrm{a}\end{array}$ & $\begin{array}{c}\text { Ineffective } \\
1.20 \times 10^{-4} \mathrm{a}\end{array}$ & $\begin{array}{c}\text { Ineffective } \\
1.20 \times 10^{-4} \text { a }\end{array}$ \\
\hline
\end{tabular}

QAC 1-benzyl-C12-18-alkydimethyl ammonium chlorides; QAC 2—benzyl-C12-16 alkyldimethyl chlorides; QAC 3—didecyldimethylammonium chloride, benzyl-C12-16-alkyldimethyl chlorides; OA 1-hydrogen peroxide, silver nitrate; OA 2-perlactic acid; OA 3-peracetic acid, hydrogen peroxide bis (sulphate) bis (peroxymonosulfate); OA 4-pentapotassium, benzenesulfonic acid, C10-13 alkyl derivatives, sodium salts, malic acid, sulfamic acid; ChC 1—chlorine dioxide; ChC 2-hypochlorous acid calcium salt; IC 1-iodine, IC 2-iodine; NANO 1-nanocopper; NANO 2-nanosilver; LMO-ATCC - L. monocytogenes ATCC 19111, LMO-W—-strain isolated from vegetables, LMO-M-strain isolated from meat, LMO-N—strain isolated from dairy products, LMO-R—strain isolated from fish, LMO-K—clinical strain, a-l—values marked with different letters differ statistically significantly ( $p \leq 0.05)$. 


\subsection{Assessment of the Stability of QAC 2,OA 3, and ChC1 Solutions}

Three disinfectants, for which the effectiveness coefficient was the lowest, were evaluated for the stability (QAC 2, OA 3, and ChC 1). The prepared working solutions, both in non-ozonated and ozonated water, were stored at room temperature. The effectiveness of these agents on L. monocytogenes strains was evaluated immediately after preparation of the solutions, after 12 and $24 \mathrm{~h}$, determining the MBC values in individual time intervals. This part of the experiment was designed to assess whether the possible increased effectiveness of disinfectants is not prolonged due to some reactions between ozone and active substances. On the basis of MBC values, the coefficient A was calculated for particular disinfectant, strains and time of storage.

\subsection{Statistical Analysis}

Statistical analysis was performed in the STATISTICA 13.1 PL program (StatSoft). Significance of differences between the ozonated water effectiveness, $M B C$ values of disinfectants, reduction in L. monocytogenes number and maximal effectiveness coefficients for disinfectants were assessed.

\subsubsection{Biocidal Effectiveness of Ozonated and Non-Ozonated Water}

It was checked how the MBC value of the ozonated water varied depending on the time $(0,1$, and $2 \mathrm{~h}$ ) and the L. monocytogenes strain. Experiment was made in 3 replications. As independent variables, the strain as well as the time elapsed from the ozonation of water were treated, and as a dependent variable the determined value of MBC was recognized. Significance of differences between mean MBC values for the combination of both independent variables was checked. For this purpose, the general line models (GLM) were used. The multi-way ANOVA was conducted. The Tukey post-hoc test was used for significance of $\alpha=0.05$.

\subsubsection{Evaluation of the Effectiveness of Disinfectants}

It was checked how the MBC value of tested disinfectants varied depending on the type of water (ozonated/non-ozonated) used for solutions preparation. Experiment was made in 3 replications. As independent variables, the disinfectant, type of water, as well as the strain were treated, and as a dependent variable the determined value of disinfectants MBC was recognized. Significance of differences between mean $\mathrm{MBC}$ values for the combination of all independent variables was checked. For this purpose, the general line models (GLM) were used. The multi-way ANOVA was conducted. The Tukey post-hoc test was used for significance of $\alpha=0.05$.

\subsubsection{Reduction in Bacteria Number}

It was checked how the reduction in bacteria number varied depending on the type of water (ozonated/non-ozonated) used for disinfecting solutions preparation. Experiment was made in 3 replications. As independent variables, the type of water was treated, and as a dependent variable the determined reduction in bacteria number was recognized. Significance of differences between mean reduction obtained for particular disinfectant depending on type of water was checked. For this purpose, the general line models (GLM) were used. The one-way ANOVA was conducted. The Tukey post-hoc test was used for significance of $\alpha=0.05$.

\subsubsection{Maximal Effectiveness Coefficients for Disinfectants}

It was checked how the maximal effectiveness coefficients for disinfectants varied depending on the type of water (ozonated/non-ozonated) used for disinfecting solutions preparation. Experiment was made in 3 replications. As independent variables, the type of water was treated, and as a dependent variable the determined maximal effectiveness coefficients for disinfectants was recognized. Significance of differences between mean coefficient value obtained for particular disinfectant depending on type of 
water was checked. For this purpose, the general line models (GLM) were used. The one-way ANOVA was conducted. The Tukey post-hoc test was used for significance of $\alpha=0.05$.

\section{Results}

\subsection{Assessment of Biocidal Effectiveness of Ozonated and Non-Ozonated Water}

The non-ozonated water did not show biocidal efficacy against the tested strains of L. monocytogenes.

The determined concentration of ozone in ozonated water was $2.32 \mu \mathrm{g} / \mathrm{mL}( \pm 0.022 \mu \mathrm{g} / \mathrm{mL})$. The ozonated water, used immediately after preparation, inhibited bacterial growth at ozone concentrations $1.86-1.96 \mu \mathrm{g} / \mathrm{mL}$, with the lowest resistance characterized for the reference strain $(1.86 \mu \mathrm{g} / \mathrm{mL})$ and the highest-for strains derived from meat and fish $(1.96 \mu \mathrm{g} / \mathrm{mL})$. For the ozonated water after two $\mathrm{h}$ from the end of the ozonation process, for all tested L. monocytogenes strains, the total lack of efficacy was demonstrated (Figure 1).

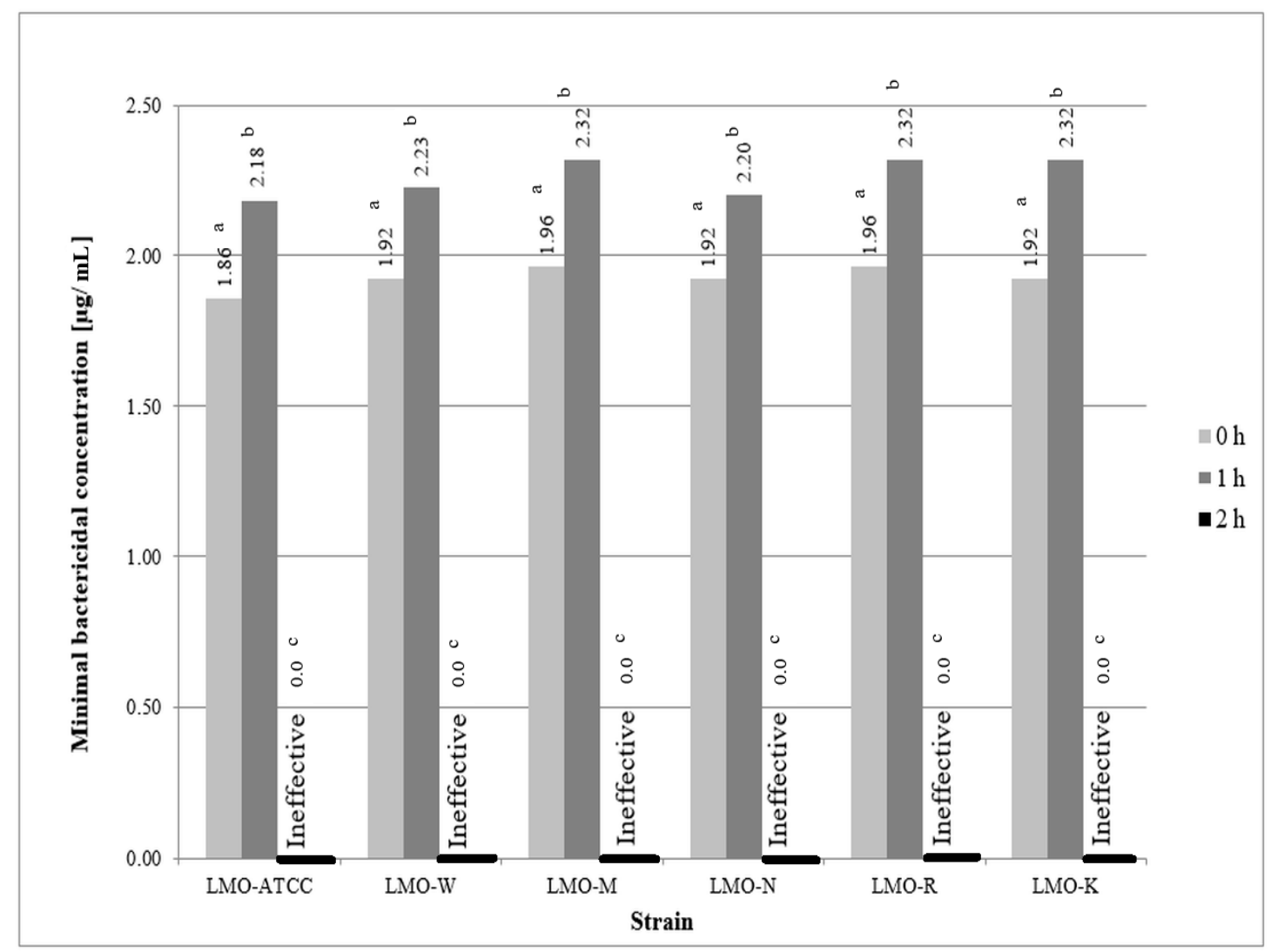

Figure 1. Effectiveness of ozonated water against the tested strains of L. monocytogenes (LMO-ATCCL. monocytogenes ATCC 19111, LMO-W—strain isolated from vegetables, LMO-M—strain isolated from meat, LMO-N—strain isolated from dairy products, LMO-R—strain isolated from fish, LMO-K—clinical strain.; $a, b, c-$ variables with different letters are statistically different $(p \leq 0.05)$.

\subsection{Evaluation of Effectiveness of Disinfectant}

Disinfectants based on ozonated water were characterized by a higher biocidal efficiency than solutions based on non-ozonated water (Table 3). In most cases these differences were statistically significant $(p \leq 0.05)$ (Table 3).

Among the tested disinfectants, regardless of type of water used for preparation, the most effective against L. monocytogenes were: QAC $1\left(1.00 \times 10^{-5}-1.00 \times 10^{-4} \mathrm{~g} / \mathrm{mL}\right)$ in quaternary ammonium compounds, OA $3\left(3.08 \times 10^{-4}-3.70 \times 10^{-3} \mathrm{~g} / \mathrm{mL}\right)$ in oxidizing agents, ChC $1\left(5.00 \times 10^{-8}-7.00\right.$ $\left.\times 10^{-7} \mathrm{~g} / \mathrm{mL}\right)$ in chlorine compounds, IC $1(1.05-2.15 \mathrm{~g} / \mathrm{mL})$ in iodine compounds and NANO 1 
$\left(1.08 \times 10^{-4}-1.47 \times 10^{-4} \mathrm{~g} / \mathrm{mL}\right)$ in nanoparticles (Table 3). In case of NANO 2, the solution based on non-ozonated water, was totally ineffective against all tested L. monocytogenes strains. Moreover, the OA 2 solution based on non-ozonated water was also ineffective against LMO-W, LMO-M and LMO-R strains (Table 3).

The MBC value of tested disinfectants determined for particular examined strains of L. monocytogenes were very similar, so the effect was not strain-dependent. None strain-dependent differences in MBC were stated in case of QAC 2, QAC 3, OA 1, OA 4 and NANO 2 (Table 3). In all cases the concentration of disinfectants equal MBC value cause decrease in bacteria number below the detection limit. In Table 4, the logarithmic decreases in bacteria number after using the disinfectant concentration directly preceding $\mathrm{MBC}$ (preMBC), for solution based on ozonated and non-ozonated water, are presented. For solutions of disinfectants prepared on the basis of ozonated water, the determined preMBC values were lower, and despite this the logarithmic decreases in the number of L. monocytogenes were found to be higher. The observed differences in decreases were, in most cases, statistically significant $(p \leq 0.05)$ (Table 4$)$.

Table 4. Logarithmic decreases in bacteria number after using the disinfectant concentration directly preceding MBC (preMBC).

\begin{tabular}{|c|c|c|c|c|c|c|c|c|}
\hline \multirow{3}{*}{$\begin{array}{c}\text { Group of } \\
\text { Disinfectants }\end{array}$} & \multirow{3}{*}{ Disinfectant } & \multirow{3}{*}{ Water Type } & \multicolumn{6}{|c|}{ Reduction in Bacteria Number (log CFU) } \\
\hline & & & \multicolumn{6}{|c|}{ Strain } \\
\hline & & & LMO-AT & MO-W & LMO-M & LMO-N & LMO-R & LMO-K \\
\hline \multirow{9}{*}{$\begin{array}{l}\text { Quaternary } \\
\text { ammonium } \\
\text { compounds }\end{array}$} & \multirow{3}{*}{ QAC 1} & Initial no. & 8.81 & 8.69 & 8.71 & 8.76 & 8.66 & 8.73 \\
\hline & & Nonozonated & $7.23^{a}$ & $6.96^{\mathrm{a}}$ & $6.84^{\mathrm{a}}$ & $6.92^{\mathrm{a}}$ & $6.76^{\mathrm{a}}$ & $7.07^{\mathrm{a}}$ \\
\hline & & Ozonated & $8.28^{b}$ & $8.00^{b}$ & $7.88^{b}$ & $7.97^{\mathrm{b}}$ & $7.80^{\mathrm{b}}$ & $8.12^{b}$ \\
\hline & \multirow{3}{*}{ QAC 2} & Initial no. & 8.81 & 8.69 & 8.71 & 8.76 & 8.66 & 8.73 \\
\hline & & Nonozonated & $7.05^{\mathrm{a}}$ & $6.78^{\mathrm{a}}$ & $6.62^{a}$ & $6.75^{\mathrm{a}}$ & $6.50^{\mathrm{a}}$ & $6.90^{\mathrm{a}}$ \\
\hline & & Ozonated & $7.93^{b}$ & $7.65^{b}$ & $7.62^{b}$ & $7.49^{\mathrm{a}}$ & $7.36^{\mathrm{b}}$ & $7.77^{\mathrm{b}}$ \\
\hline & \multirow{3}{*}{ QAC 3} & Initial no. & 8.81 & 8.69 & 8.71 & 8.76 & 8.66 & 8.73 \\
\hline & & Nonozonated & $6.70^{a}$ & $6.43^{\mathrm{a}}$ & $6.27^{\mathrm{a}}$ & $6.40^{\mathrm{a}}$ & $6.15^{\mathrm{a}}$ & $6.55^{a}$ \\
\hline & & Ozonated & $7.49^{\mathrm{a}}$ & $7.22^{\mathrm{a}}$ & $7.06^{\mathrm{a}}$ & $7.19^{\mathrm{a}}$ & $6.93^{\mathrm{a}}$ & $7.34^{\mathrm{a}}$ \\
\hline \multirow{12}{*}{$\begin{array}{l}\text { Oxidizing } \\
\text { agents }\end{array}$} & \multirow{3}{*}{ OA 1} & Initial no. & 8.81 & 8.69 & 8.71 & 8.76 & 8.66 & 8.73 \\
\hline & & Nonozonated & $6.52^{a}$ & $6.26^{\mathrm{a}}$ & $6.10^{a}$ & $6.22^{a}$ & $5.98^{a}$ & $6.37^{\mathrm{a}}$ \\
\hline & & Ozonated & $7.23^{b}$ & $6.96^{\mathrm{a}}$ & $6.79^{a}$ & $6.93^{\mathrm{a}}$ & $6.67^{\mathrm{a}}$ & $7.07^{\mathrm{a}}$ \\
\hline & \multirow{3}{*}{ OA 2} & Initial no. & 8.81 & 8.69 & 8.71 & 8.76 & 8.66 & 8.73 \\
\hline & & Nonozonated & $2.64^{a}$ & $2.43^{\mathrm{a}}$ & $2.37^{\mathrm{a}}$ & $2.17^{\mathrm{a}}$ & $2.26^{\mathrm{a}}$ & $2.53^{a}$ \\
\hline & & Ozonated & $5.11^{b}$ & $4.87^{\mathrm{b}}$ & $4.59^{b}$ & $4.82^{b}$ & $4.70^{b}$ & $4.98^{b}$ \\
\hline & \multirow{3}{*}{ OA 3} & Initial no. & 8.81 & 8.69 & 8.71 & 8.76 & 8.66 & 8.73 \\
\hline & & Nonozonated & $6.61^{\mathrm{a}}$ & $6.35^{\mathrm{a}}$ & $6.18^{\mathrm{a}}$ & $6.31^{\mathrm{a}}$ & $6.06^{\mathrm{a}}$ & $6.46^{\mathrm{a}}$ \\
\hline & & Ozonated & $7.40^{\mathrm{a}}$ & $7.13^{\mathrm{a}}$ & $6.97^{\mathrm{a}}$ & $7.08^{a}$ & $6.80^{\mathrm{a}}$ & $7.25^{\mathrm{a}}$ \\
\hline & \multirow{3}{*}{ OA 4} & Initial no. & 8.81 & 8.69 & 8.71 & 8.76 & 8.66 & 8.73 \\
\hline & & Nonozonated & $6.43^{a}$ & $6.18^{a}$ & $6.02^{a}$ & $6.12^{\mathrm{a}}$ & $5.83^{a}$ & $6.29^{a}$ \\
\hline & & Ozonated & $7.35^{b}$ & $7.04^{b}$ & $6.90^{\mathrm{b}}$ & $7.00^{\mathrm{b}}$ & $6.75^{b}$ & $7.10^{b}$ \\
\hline \multirow{6}{*}{$\begin{array}{l}\text { Chlorine } \\
\text { compounds }\end{array}$} & \multirow{3}{*}{ ChC 1} & Initial no. & 8.81 & 8.69 & 8.71 & 8.76 & 8.66 & 8.73 \\
\hline & & Nonozonated & $7.67^{a}$ & $7.39^{\mathrm{a}}$ & $7.23^{\mathrm{a}}$ & $7.33^{\mathrm{a}}$ & $7.06^{\mathrm{a}}$ & $7.52^{a}$ \\
\hline & & Ozonated & $8.55^{b}$ & $8.30^{\mathrm{b}}$ & $8.24^{b}$ & $8.10^{\mathrm{a}}$ & $7.91^{b}$ & $8.33^{b}$ \\
\hline & \multirow{3}{*}{ ChC 2} & Initial no. & 8.81 & 8.69 & 8.71 & 8.76 & 8.66 & 8.73 \\
\hline & & Nonozonated & $7.31^{\mathrm{a}}$ & $6.95^{a}$ & $6.71^{\mathrm{a}}$ & $6.93^{a}$ & $6.58^{\mathrm{a}}$ & $7.08^{\mathrm{a}}$ \\
\hline & & Ozonated & $7.85^{\mathrm{a}}$ & $7.56^{\mathrm{a}}$ & $7.30^{\mathrm{a}}$ & $7.55^{\mathrm{a}}$ & $7.41^{\mathrm{b}}$ & $7.65^{\mathrm{a}}$ \\
\hline
\end{tabular}


Table 4. Cont

\begin{tabular}{|c|c|c|c|c|c|c|c|c|}
\hline \multirow{3}{*}{$\begin{array}{c}\text { Group of } \\
\text { Disinfectants }\end{array}$} & \multirow{3}{*}{ Disinfectant } & \multirow{3}{*}{ Water Type } & \multicolumn{6}{|c|}{ Reduction in Bacteria Number (log CFU) } \\
\hline & & & \multicolumn{6}{|c|}{ Strain } \\
\hline & & & LMO-AT & LMO-W & LMO-M & LMO-N & LMO-R & LMO-K \\
\hline \multirow{6}{*}{$\begin{array}{c}\text { Iodine } \\
\text { compounds }\end{array}$} & \multirow{3}{*}{ IC 1} & Initial no. & 8.81 & 8.69 & 8.71 & 8.76 & 8.66 & 8.73 \\
\hline & & Nonozonated & $6.48^{\mathrm{a}}$ & $6.22^{a}$ & $6.05^{a}$ & $6.16^{\mathrm{a}}$ & $5.93^{a}$ & $6.37^{a}$ \\
\hline & & Ozonated & $7.54^{\mathrm{b}}$ & $7.26^{\mathrm{b}}$ & $7.17^{\mathrm{b}}$ & $7.31^{\mathrm{b}}$ & $7.03^{b}$ & $7.38^{b}$ \\
\hline & \multirow{3}{*}{ IC 2} & Initial no. & 8.81 & 8.69 & 8.71 & 8.76 & 8.66 & 8.73 \\
\hline & & Nonozonated & $6.49^{a}$ & $6.21^{a}$ & $6.03^{a}$ & $6.15^{a}$ & $5.90^{\mathrm{a}}$ & $6.33^{a}$ \\
\hline & & Ozonated & $7.63^{b}$ & $7.34^{\mathrm{b}}$ & $7.16^{b}$ & $7.30^{b}$ & $7.04^{b}$ & $7.47^{\mathrm{b}}$ \\
\hline \multirow{6}{*}{ Nanoparticles } & \multirow{3}{*}{ NANO 1} & Initial no. & 8.81 & 8.69 & 8.71 & 8.76 & 8.66 & 8.73 \\
\hline & & Nonozonated & $6.17^{a}$ & $5.91^{\mathrm{a}}$ & $5.75^{a}$ & $5.87^{\mathrm{a}}$ & $5.69^{a}$ & $6.03^{a}$ \\
\hline & & Ozonated & $7.05^{b}$ & $6.79^{b}$ & $6.62^{b}$ & $6.75^{b}$ & $6.50^{b}$ & $6.90^{\mathrm{b}}$ \\
\hline & \multirow{3}{*}{ NANO 2} & Initial no. & 8.81 & 8.69 & 8.71 & 8.76 & 8.66 & 8.73 \\
\hline & & Nonozonated & $1.76^{\mathrm{a}}$ & $1.57^{\mathrm{a}}$ & $1.30^{\mathrm{a}}$ & $1.49^{\mathrm{a}}$ & $1.37^{\mathrm{a}}$ & $1.66^{\mathrm{a}}$ \\
\hline & & Ozonated & $6.03^{b}$ & $5.75^{\mathrm{b}}$ & $5.87^{b}$ & $5.91^{\mathrm{b}}$ & $5.63^{b}$ & $6.17^{b}$ \\
\hline
\end{tabular}

QAC 1-benzyl-C12-18-alkydimethyl ammonium chlorides; QAC 2-benzyl-C12-16 alkyldimethyl chlorides; QAC 3-didecyldimethylammonium chloride, benzyl-C12-16-alkyldimethyl chlorides; OA 1-hydrogen peroxide, silver nitrate; OA 2-perlactic acid; OA 3-peracetic acid, hydrogen peroxide bis (sulphate) bis (peroxymonosulfate); OA 4-pentapotassium, benzenesulfonic acid, C10-13 alkyl derivatives, sodium salts, malic acid, sulfamic acid; ChC 1-chlorine dioxide; ChC 2-hypochlorous acid calcium salt; IC 1-iodine, IC 2-iodine; NANO 1-nanocopper; NANO 2-nanosilver; LMO-ATCC — L. monocytogenes ATCC 19111, LMO-W—strain isolated from vegetables, LMO-M - strain isolated from meat, LMO-N—strain isolated from dairy products, LMO-R—strain isolated from fish, LMO-K—clinical strain, a,b-values marked with different letters differ statistically significantly $(p \leq 0.05)$ (Tested separately for each disinfectant and each strain depending on water type-ozonated/non-ozonated).

\subsection{Coefficients of Effectiveness of Disinfectants}

The values of the activity coefficient for all strains and disinfectants are shown in Table 5 . These values for quaternary ammonium compounds ranged from 0.10 to 0.40 , for oxidizing agents-from 0.15 to 0.84 , for chlorine compounds-from 0.25 to 0.83 , for iodine compounds-from 0.45 to 0.60 and for nanoparticles-from 0.70 to 0.84 (Table 5). It was shown, ozonated water had the greatest impact on the efficiency of the quaternary ammonium compounds whereas did not significantly improve the effectiveness of nanoparticles (Figure 2).

Table 5. Efficiency coefficient values for tested strains and disinfectants.

\begin{tabular}{|c|c|c|c|c|c|c|}
\hline \multirow{3}{*}{ Disinfectant } & \multicolumn{6}{|c|}{ Efficiency Coefficient (A) } \\
\hline & \multicolumn{6}{|c|}{ Strain } \\
\hline & LMO-ATCC & LMO-W & LMO-M & LMO-N & LMO-R & LMO-K \\
\hline QAC 1 & $0.40^{\mathrm{a}}$ & $0.20^{\mathrm{b}}$ & $0.25^{\mathrm{b}, \mathrm{g}}$ & $0.25^{b, g}$ & $0.25^{\mathrm{b}, \mathrm{g}}$ & $0.40^{\mathrm{a}}$ \\
\hline QAC 2 & $0.10^{\mathrm{c}, \mathrm{f}}$ & $0.10^{\mathrm{c}, \mathrm{f}}$ & $0.10^{\mathrm{c}, \mathrm{f}}$ & $0.10^{\mathrm{c}, \mathrm{f}}$ & $0.10^{\mathrm{c}, \mathrm{f}}$ & $0.10^{\mathrm{c}, \mathrm{f}}$ \\
\hline QAC 3 & $0.10^{\mathrm{c}, \mathrm{f}}$ & $0.20^{\mathrm{b}}$ & $0.10^{\mathrm{c}, \mathrm{f}}$ & $0.10^{\mathrm{c}, \mathrm{f}}$ & $0.10^{\mathrm{c}, \mathrm{f}}$ & $0.10^{\mathrm{c}, \mathrm{f}}$ \\
\hline OA 1 & $0.84^{\mathrm{d}}$ & $0.84^{\mathrm{d}}$ & $0.84^{\mathrm{d}}$ & $0.84^{\mathrm{d}}$ & $0.84^{\mathrm{d}}$ & $0.84^{\mathrm{d}}$ \\
\hline OA 2 & $0.55^{\mathrm{e}, \mathrm{i}}$ & Ineffective & Ineffective & $0.55^{\mathrm{e}, \mathrm{i}}$ & Ineffective & $0.55^{\mathrm{e}, \mathrm{i}}$ \\
\hline OA 3 & $0.22^{b}$ & $0.22^{\mathrm{b}}$ & $0.23^{\mathrm{b}}$ & $0.17^{\mathrm{b}, \mathrm{f}}$ & $0.15^{\mathrm{b}, \mathrm{f}}$ & $0.22^{b}$ \\
\hline OA 4 & $0.38^{a}$ & $0.38^{a}$ & $0.38^{a}$ & $0.38^{\mathrm{a}}$ & $0.38^{a}$ & $0.38^{\mathrm{a}}$ \\
\hline ChC 1 & $0.25^{\mathrm{b}, \mathrm{g}}$ & $0.25^{\mathrm{b}, \mathrm{g}}$ & $0.43^{a}$ & $0.25^{\mathrm{b}, \mathrm{g}}$ & $0.33^{\mathrm{a}, \mathrm{g}}$ & $0.25^{\mathrm{b}, \mathrm{g}}$ \\
\hline $\mathrm{ChC} 2$ & $0.83^{d}$ & $0.63^{\mathrm{e}, \mathrm{h}}$ & $0.56^{\mathrm{e}}$ & $0.63^{\mathrm{e}, \mathrm{h}}$ & $0.71^{h, j}$ & $0.70^{h, j}$ \\
\hline IC 1 & $0.49^{\mathrm{a}, \mathrm{i}}$ & $0.60^{\mathrm{e}, \mathrm{h}}$ & $0.60^{\mathrm{e}, \mathrm{h}}$ & $0.60^{\mathrm{e}, \mathrm{h}}$ & $0.60^{\mathrm{e}, \mathrm{h}}$ & $0.49^{\mathrm{a}, \mathrm{i}}$ \\
\hline IC 2 & $0.45^{\mathrm{a}, \mathrm{i}}$ & $0.45^{\mathrm{a}, \mathrm{i}}$ & $0.45^{\mathrm{a}, \mathrm{i}}$ & $0.45^{\mathrm{a}, \mathrm{i}}$ & $0.45^{\mathrm{a}, \mathrm{i}}$ & $0.45^{\mathrm{a}, \mathrm{i}}$ \\
\hline NANO 1 & $0.70^{h, j}$ & $0.84^{\mathrm{d}}$ & $0.81^{\mathrm{d}}$ & $0.79^{\mathrm{d}, j}$ & $0.81^{\mathrm{d}}$ & $0.79^{\mathrm{d}, j}$ \\
\hline NANO 2 & Ineffective & Ineffective & Ineffective & Ineffective & Ineffective & Ineffective \\
\hline
\end{tabular}

QAC 1-benzyl-C12-18-alkydimethyl ammonium chlorides; QAC 2-benzyl-C12-16 alkyldimethyl chlorides; QAC 3-didecyldimethylammonium chloride, benzyl-C12-16-alkyldimethyl chlorides; OA 1-hydrogen peroxide, silver nitrate; OA 2-perlactic acid; OA 3-peracetic acid, hydrogen peroxide bis (sulphate) bis (peroxymonosulfate); OA 4-pentapotassium, benzenesulfonic acid, C10-13 alkyl derivatives, sodium salts, malic acid, sulfamic acid; ChC 1-chlorine dioxide; ChC 2-hypochlorous acid calcium salt; IC 1-iodine, IC 2-iodine; NANO 1-nanocopper; NANO 2-nanosilver; LMO-ATCC_L. monocytogenes ATCC 19111, LMO-W-strain isolated from vegetables, LMO-M-strain isolated from meat, LMO-N—strain isolated from dairy products, LMO-R—strain isolated from fish, LMO-K—clinical strain, a-j-values marked with different letters differ statistically significantly $(p \leq 0.05)$. 


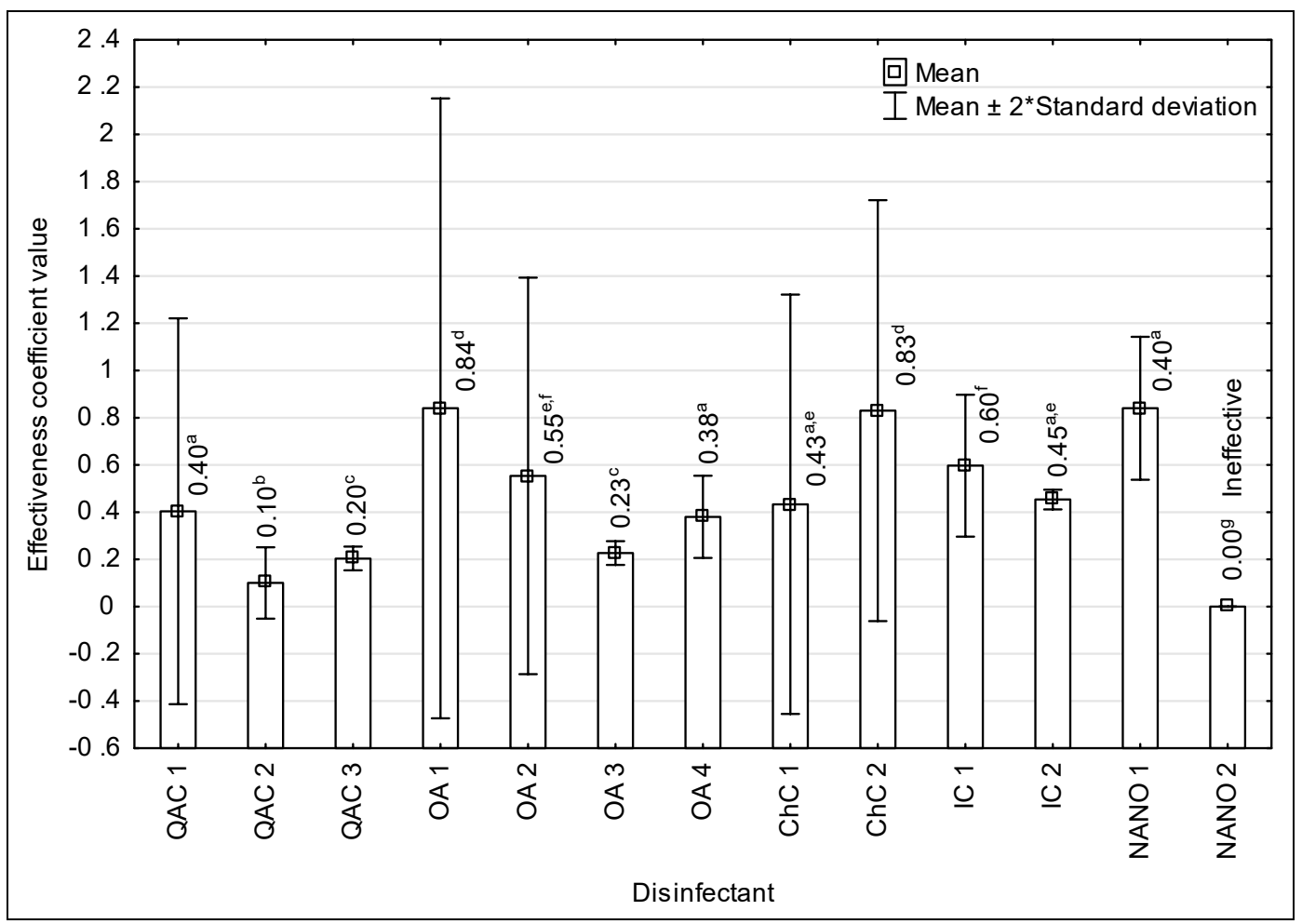

Figure 2. Values of efficacy coefficients for the tested disinfectants, including their belonging to distinguished groups (QAC-quaternary ammonium compounds, OA-oxidizing agents, ChC—chlorine compounds, IC—iodine compounds, NANO—nanoparticles); a-g—variables with different letters are statistically different $(p \leq 0.05)$

It was not possible to select the L. monocytogenes strain, for which the increase in the effectiveness of all tested disinfectants would be the greatest or the smallest after preparation of solutions with ozonated water (Table 5).

The lowest maximal value of the efficacy coefficient, and therefore the highest increase in microbicidal effectiveness after using ozonated water, was demonstrated for QAC $2(0.10)$ and QAC $3(0.20)$ and OA $3(0.23)$. The values of the efficacy coefficient differ significantly $(p>0.05)$ between QAC 2 versus QAC 3 and OA 3 (Figure 2). The highest maximal efficacy coefficients, indicating a small improvement in the bactericidal effectiveness of solutions based on ozonated water in relation to solutions prepared with non-ozonated water, were found for OA $1(0.84), \mathrm{ChC} 2(0.83)$ and NANO 1 (0.84). The above values of coefficients differed statistically significantly $(p \leq 0.05)$ with the majority of values calculated for the remaining disinfectants (Figure 2).

\subsection{Assessment of the Stability of $\mathrm{QAC} 2, \mathrm{OA} 3$, and ChC 1 Solutions}

QAC 2, OA 3, and $\mathrm{ChC} 1$ were chosen as the agents from different groups with the lowest maximal value of efficacy to assess the stability of the solutions. The stability results of the tested solutions are shown in Table 6.

It has been shown that during the storage of disinfectant solutions, their biocidal activity decreases against L. monocytogenes strains. Decrease in the biocidal activity of disinfectant solutions, which were prepared using both ozonated and non-ozonated water, was observed. The greater decrease in biocidal activity was visible for solutions prepared with the use of ozonated water (Table 6).

The activity of the QAC 2 solutions decreased over all tested strains after $24 \mathrm{~h}$ of storage, both for solutions with non-ozonated and ozonated water. In the case of OA 3 and ChC 1 disinfectants, a decrease in activity was observed for all tested strains of L. monocytogenes after 12 and $24 \mathrm{~h}$ of storage, for both type of water used for solutions preparation (Table 6). 
Table 6. Stability assessment of stored solutions of QAC 2, OA 3, and ChC 1 after 0.12 and $24 \mathrm{~h}$.

\begin{tabular}{|c|c|c|c|c|c|c|c|c|}
\hline \multirow{3}{*}{ Disinfectant } & \multirow{3}{*}{ Water Type } & \multirow{3}{*}{$\begin{array}{l}\text { Storage Time } \\
\text { (h) }\end{array}$} & \multicolumn{6}{|c|}{ Minimal Bactericidal Concentration of Disinfectant $\left[\mathrm{g} / \mathrm{cm}^{3}\right]$} \\
\hline & & & \multicolumn{6}{|c|}{ Strain } \\
\hline & & & LMO-ATCC & LMO-W & LMO-M & LMO-N & LMO-R & LMO-K \\
\hline \multirow{6}{*}{$\begin{array}{l}\text { QAC } 2 \text { (working } \\
\text { solution: } 2.55 \times 10^{0} \\
\mathrm{~g} / \mathrm{mL} \text { ) }\end{array}$} & \multirow{3}{*}{ Nonozonated } & 0 & $1.28 \times 10^{-4} \mathrm{a}$ & $1.28 \times 10^{-4 \mathrm{a}}$ & $1.28 \times 10^{-4} \mathrm{a}$ & $1.28 \times 10^{-4 \mathrm{a}}$ & $1.28 \times 10^{-4 \mathrm{a}}$ & $1.28 \times 10^{-4} \mathrm{a}$ \\
\hline & & 12 & $1.28 \times 10^{-4 a}$ & $1.28 \times 10^{-4 \mathrm{a}}$ & $1.28 \times 10^{-4} \mathrm{a}$ & $1.28 \times 10^{-4 a}$ & $1.28 \times 10^{-4 a}$ & $1.28 \times 10^{-4} \mathrm{a}$ \\
\hline & & 24 & $1.53 \times 10^{-4 \mathrm{a}}$ & $1.53 \times 10^{-4 \mathrm{a}}$ & $1.53 \times 10^{-4 \mathrm{a}}$ & $1.53 \times 10^{-4 \mathrm{a}}$ & $1.53 \times 10^{-4 \mathrm{a}}$ & $1.53 \times 10^{-4 \mathrm{a}}$ \\
\hline & \multirow{3}{*}{ Ozonated } & 0 & $1.28 \times 10^{-5 b}$ & $1.28 \times 10^{-5 b}$ & $1.28 \times 10^{-5 b}$ & $1.28 \times 10^{-5 b}$ & $1.28 \times 10^{-5 b}$ & $1.28 \times 10^{-5 b}$ \\
\hline & & 12 & $1.02 \times 10^{-4} \mathrm{a}$ & $1.28 \times 10^{-5 b}$ & $1.28 \times 10^{-5 b}$ & $1.28 \times 10^{-5 b}$ & $1.28 \times 10^{-5 b}$ & $1.02 \times 10^{-4 a}$ \\
\hline & & 24 & $1.53 \times 10^{-4 \mathrm{a}}$ & $1.53 \times 10^{-4} \mathrm{a}$ & $1.53 \times 10^{-4 \mathrm{a}}$ & $1.53 \times 10^{-4 a}$ & $1.79 \times 10^{-4 a}$ & $1.53 \times 10^{-4 \mathrm{a}}$ \\
\hline \multirow{6}{*}{$\begin{array}{l}\text { OA } 3 \text { (working solution: } \\
\quad 6.15 \times 10^{-3} \mathrm{~g} / \mathrm{mL} \text { ) }\end{array}$} & \multirow{3}{*}{ Nonozonated } & 0 & $1.42 \times 10^{-3 c}$ & $1.42 \times 10^{-3 c} \mathrm{c}$ & $1.42 \times 10^{-3 c} \mathrm{c}$ & $1.80 \times 10^{-3 c}$ & $3.81 \times 10^{-3 \mathrm{~d}, \mathrm{f}}$ & $1.42 \times 10^{-3 c}$ \\
\hline & & 12 & $1.66 \times 10^{-3 c}$ & $1.72 \times 10^{-3 c} \mathrm{c}$ & $2.40 \times 10^{-3 c, d}$ & $2.20 \times 10^{-3 c, d}$ & $4.30 \times 10^{-3} \mathrm{e}, \mathrm{f}$ & $1.60 \times 10^{-3 c}$ \\
\hline & & 24 & $2.40 \times 10^{-3 c, d}$ & $2.58 \times 10^{-3 c, d}$ & $3.40 \times 10^{-3 \mathrm{~d}}$ & $3.20 \times 10^{-3 \mathrm{~d}}$ & $5.23 \times 10^{-3} \mathrm{e}$ & $2.50 \times 10^{-3 c, d}$ \\
\hline & \multirow{3}{*}{ Ozonated } & 0 & $3.10 \times 10^{-4 \mathrm{~g}}$ & $3.10 \times 10^{-4 g}$ & $4.30 \times 10^{-4 g}$ & $3.10 \times 10^{-4} \mathrm{~g}$ & $6.15 \times 10^{-4 h}$ & $2.46 \times 10^{-4 \mathrm{~g}}$ \\
\hline & & 12 & $1.60 \times 10^{-3 c}$ & $1.66 \times 10^{-3 c}$ & $2.40 \times 10^{-3 c, d}$ & $2.15 \times 10^{-3} \mathrm{c}, \mathrm{d}$ & $4.12 \times 10^{-3} \mathrm{e}, \mathrm{f}$ & $1.60 \times 10^{-3 c}$ \\
\hline & & 24 & $2.40 \times 10^{-3} \mathrm{c}, \mathrm{d}$ & $2.65 \times 10^{-3 c, d}$ & $3.40 \times 10^{-3 \mathrm{~d}}$ & $3.9 \times 10^{-3 \mathrm{~d}, \mathrm{f}}$ & $5.10 \times 10^{-3 e}$ & $2.50 \times 10^{-3 c, d}$ \\
\hline \multirow{6}{*}{$\begin{array}{c}\text { ChC } 1 \text { (working } \\
\text { solution: } 1.00 \times 10^{-5} \\
\mathrm{~g} / \mathrm{mL} \text { ) }\end{array}$} & \multirow{3}{*}{ Nonozonated } & 0 & $2.00 \times 10^{-7 i}$ & $4.00 \times 10^{-7 \mathrm{i}, \mathrm{k}}$ & $7.00 \times 10^{-7 j}$ & $4.00 \times 10^{-7 \mathrm{i}, \mathrm{k}}$ & $6.00 \times 10^{-7 \mathrm{j}, \mathrm{k}}$ & $4.00 \times 10^{-7 \mathrm{i}, \mathrm{k}}$ \\
\hline & & 12 & $3.00 \times 10^{-7 i}$ & $6.00 \times 10^{-7 \mathrm{j}, \mathrm{k}}$ & $8.00 \times 10^{-7 j}$ & $5.00 \times 10^{-7 \mathrm{i}, \mathrm{k}}$ & $8.00 \times 10^{-7 j}$ & $5.00 \times 10^{-7 \mathrm{i}, \mathrm{k}}$ \\
\hline & & 24 & $5.00 \times 10^{-7 \mathrm{i}, \mathrm{k}}$ & $8.00 \times 10^{-7 j}$ & $1.00 \times 10^{-61}$ & $7.00 \times 10^{-7 j}$ & $1.10 \times 10^{-61}$ & $7.00 \times 10^{-7 j}$ \\
\hline & \multirow{3}{*}{ Ozonated } & 0 & $5.00 \times 10^{-8} \mathrm{~m}$ & $1.00 \times 10^{-7 i}$ & $3.00 \times 10^{-7 i}$ & $1.00 \times 10^{-7 i}$ & $2.00 \times 10^{-7 i}$ & $1.00 \times 10^{-7 i}$ \\
\hline & & 12 & $2.00 \times 10^{-7 i}$ & $5.00 \times 10^{-7 \mathrm{i}, \mathrm{k}}$ & $8.00 \times 10^{-7 j}$ & $5.00 \times 10^{-7 \mathrm{i}, \mathrm{k}}$ & $8.00 \times 10^{-7 j}$ & $4.00 \times 10^{-7 \mathrm{i}, \mathrm{k}}$ \\
\hline & & 24 & $5.00 \times 10^{-7 \mathrm{i}, \mathrm{k}}$ & $8.00 \times 10^{-7 j}$ & $1.00 \times 10^{-61}$ & $8.00 \times 10^{-7 j}$ & $1.10 \times 10^{-61}$ & $7.00 \times 10^{-7 j}$ \\
\hline
\end{tabular}

QAC 2-benzyl-C12-16 alkyldimethyl chlorides; OA 3-peracetic acid, hydrogen peroxide bis (sulphate) bis (peroxymonosulfate); ChC 1—chlorine dioxide; LMO-ATCC-L. monocytogenes

ATCC 19111, LMO-W—strain isolated from vegetables, LMO-M—strain isolated from meat, LMO-N—strain isolated from dairy products, LMO-R—strain isolated from fish, LMO-K—clinical strain, a-m-values marked with different letters differ statistically significantly $(p \leq 0.05)$ 
For all the disinfectants included in this part of the study, a gradual increase in the efficiency coefficient was observed during storage (Table 7). For OA 3 and $\mathrm{ChC} 1$, after $12 \mathrm{~h}$ from preparation, the antilisterial effectiveness of the solution based on ozonated and non-ozonated water was almost identical. For QAC 2, this was observed after $24 \mathrm{~h}$ (Table 7). After $24 \mathrm{~h}$, in the case of QAC 2 for LMO-R strain, OA 3 strains for LMO-W and LMO-N strains and ChC 1 for LMO-N strain, the effectiveness of solution based on ozonated water was lower than for those prepared on non-ozonated water (Table 7).

Table 7. Efficiency coefficient values for tested strains and disinfectants after storage of solutions.

\begin{tabular}{|c|c|c|c|c|c|c|c|}
\hline \multirow{3}{*}{ Disinfectant } & \multirow{3}{*}{$\begin{array}{l}\text { Storage } \\
\text { Time (h) }\end{array}$} & \multicolumn{6}{|c|}{ Efficiency Coefficient (A) } \\
\hline & & \multicolumn{6}{|c|}{ Strain } \\
\hline & & LMO-ATCC & LMO-W & LMO-M & LMO-N & LMO-R & LMO-K \\
\hline \multirow{3}{*}{$\begin{array}{l}\text { QAC } 2 \text { (working solution: } \\
\quad 2.55 \times 10^{0} \mathrm{~g} / \mathrm{mL} \text { ) }\end{array}$} & 0 & $0.10^{\mathrm{a}}$ & $0.10^{a}$ & $0.10^{\mathrm{a}}$ & $0.10^{\mathrm{a}}$ & $0.10^{\mathrm{a}}$ & $0.10^{\mathrm{a}}$ \\
\hline & 12 & $0.80^{b}$ & $0.10^{\mathrm{a}}$ & $0.10^{\mathrm{a}}$ & $0.10^{\mathrm{a}}$ & $0.10^{\mathrm{a}}$ & $0.80^{\mathrm{b}}$ \\
\hline & 24 & $1.00^{b, c}$ & $1.00^{b, c}$ & $1.00^{b, c}$ & $1.00^{b, c}$ & $1.17^{\mathrm{c}}$ & $1.00^{b, c}$ \\
\hline \multirow{3}{*}{$\begin{array}{l}\text { OA } 3 \text { (working solution: } \\
6.15 \times 10^{-3} \mathrm{~g} / \mathrm{mL} \text { ) }\end{array}$} & 0 & $0.22^{\mathrm{a}}$ & $0.22^{\mathrm{a}}$ & $0.23^{a}$ & $0.17^{\mathrm{a}}$ & $0.16^{\mathrm{a}}$ & $0.17^{\mathrm{a}}$ \\
\hline & 12 & $0.96^{\mathrm{b}}$ & $0.96^{b}$ & $1.00^{b, c}$ & $0.97^{b}$ & $0.96^{\mathrm{b}}$ & $1.00^{b, c}$ \\
\hline & 24 & $1.00^{b, c}$ & $1.02^{b, c}$ & $1.00^{\mathrm{b}, \mathrm{c}}$ & $1.06^{b, c}$ & $0.98^{b, c}$ & $1.00^{b, c}$ \\
\hline \multirow{3}{*}{$\begin{array}{l}\text { ChC } 1 \text { (working solution: } \\
1.00 \times 10^{-5} \mathrm{~g} / \mathrm{mL} \text { ) }\end{array}$} & 0 & $0.25^{\mathrm{a}, \mathrm{e}}$ & $0.25^{\mathrm{a}}$ & $0.43^{\mathrm{d}}$ & $0.25^{\mathrm{a}, \mathrm{e}}$ & $0.33^{\mathrm{d}, \mathrm{e}}$ & $0.25^{\mathrm{a}, \mathrm{e}}$ \\
\hline & 12 & $0.67^{\mathrm{f}}$ & $0.83^{b}$ & $1.00^{b, c}$ & $1.00 \mathrm{~b}, \mathrm{c}$ & $1.00^{b, c}$ & $0.80^{\mathrm{b}}$ \\
\hline & 24 & $1.00^{b, c}$ & $1.00^{b, c}$ & $1.00^{b, c}$ & $1.14^{\mathrm{b}, \mathrm{c}}$ & $1.00^{b, c}$ & $1.00^{b, c}$ \\
\hline
\end{tabular}

QAC 2-benzyl-C12-16 alkyldimethyl chlorides; OA 3-peracetic acid, hydrogen peroxide bis (sulphate) bis (peroxymonosulfate); ChC 1—chlorine dioxide; LMO-ATCC—L. monocytogenes ATCC 19111, LMO-W—strain isolated from vegetables, LMO-M-strain isolated from meat, LMO-N—strain isolated from dairy products, LMO-R—strain isolated from fish, LMO-K—clinical strain, a-f-values marked with different letters differ statistically significantly $(p \leq 0.05)$.

\section{Discussion}

Ozone is one of the strongest disinfectants, which are active after a short contact time and in low concentration. It has biocidal effect on many types of microorganisms [4]. Muthukumar and Muthuchama's [20] studies confirmed a decrease in the number of microorganisms by $2.00 \times 10^{6} \mathrm{CFU}$ in $1 \mathrm{~g}$ of raw chicken samples. While Sheelamary and Muthukumar [21] showed complete inactivation of microorganisms isolated from samples of milk and its products after only $15 \mathrm{~min}$ with emission of $0.2 \mathrm{~g} \mathrm{O}_{3} / \mathrm{h}$.

In the literature, research work on the evaluation of the effectiveness of gas ozone in combination with various physical methods has been found [22-25]. Sung et al. [23] examined the action of gas ozone and high temperature on inactivation of L. monocytogenes present in apple juice. The synergistic effect was obtained when the temperature was $50^{\circ} \mathrm{C}$. Kumar et al. [25] during a 10-min exposure to ozone gas and UV showed a decrease in the number of L. monocytogenes in fresh brine by more than $9 \log \mathrm{CFU} / \mathrm{mL}$, and hourly ozonation combined with ten-minute UV irradiation resulted in a reduction of microbes over $5 \log \mathrm{CFU} / \mathrm{mL}$ in used brines. The effect of low concentrations of ozone and metal ions in the reduction of L. monocytogenes was studied by Kang et al. [26], who showed that the use of ozone in concentrations of 0.2 and $0.4 \mathrm{ppm}$ in combination with $1 \mathrm{mM} \mathrm{CuCl}_{2}$ and $0.1 \mathrm{mM} \mathrm{AgNO}_{3}$ by $30 \mathrm{~min}$ is much more effective than using ozonated water $(p<0.05)$ only. Marino et al. [27] evaluated the effect of gas ozone and ozone in water on the survival of Pseudomonas fluorescens, Staphylococcus aureus, and L. monocytogenes cells in the biofilm structure on the surface of stainless steel. They showed that the use of ozone in the aqueous solution affected the reduction of the number of bacteria by 1.61-2.14 log $\mathrm{CFU} / \mathrm{cm}^{2}$ after $20 \mathrm{~min}$ exposure, while the reduction values were higher $\left(3.26-5.23 \log \mathrm{CFU} / \mathrm{cm}^{2}\right)$ in the case of biofilms treated with ozone under dynamic flow conditions. They also showed that $S$. aureus was the most sensitive species for ozone dissolved in water [27]. Korany et al. [28] showed that the use of ozonated water $(1 \mathrm{~min})$ against the structure of L. monocytogenes biofilm on the surface of polystyrene at the concentration of 1.0, 2.0, and $4.0 \mathrm{ppm}$ resulted in a bacterial number reduction of $0.9,3.4$, and 4.1 $\log \mathrm{CFU} / \mathrm{cm}^{2}$, respectively. Moreover Korany et al. [28] found that quaternary ammonium compounds (QAC) (100/400 ppm), chlorine (100/200 ppm), chlorine dioxide (2.5/5.0 ppm) and peracetic acid (PAA) 
(80/160 ppm) resulted in a reduction of 2.4/3.6, 2.0/3.1, 2.4/3.8, and 3.6/4.8 $\log \mathrm{CFU} / \mathrm{cm}^{2}$, respectively. The antimicrobial efficacy of all tested disinfectants against the 7-day L. monocytogenes biofilm was significantly lower compared to 2-day biofilms, and the biofilm age having the minor impact on the effectiveness of PAA [28].

To date, information on the synergistic effect of ozonated water and disinfectants was not found. However, it should be expected that the implementation of a solution of disinfectants based on ozonated water will increase the effectiveness of the tested agents, at least up to the level of additive action.

In this study, the biocidal efficacy of ozonated water and non-ozonated water was evaluated. Non-ozonated water was characterized by a complete lack of biocidal activity, against all tested strains of L. monocytogenes. The ozonated water, used immediately after preparation, containing 1.86-1.96 $\mu \mathrm{g}$ $\mathrm{O}_{3} / \mathrm{cm}^{3}$, was effective for all tested isolates. The LMO-M and LMO-R strains were characterized by the highest resistance (MBC: $1.96 \mu \mathrm{g} / \mathrm{cm}^{3}$ ), and the LMO-ATCC strain (MBC: $1.86 \mu \mathrm{g} / \mathrm{cm}^{3}$ ) was the most sensitive. Fishburn et al. [29] showed that the use of ozonated water in vegetable washing can cause a decrease in the number of L. monocytogenes strains by about $0.5 \mathrm{log}$ CFU/g (broccoli, lettuce) to $1.5 \mathrm{log}$ $\mathrm{CFU} / \mathrm{g}$ (green onion), in relation to washing in non-ozonated water. Larivière-Gauthier et al. [30] have shown that the use of ozonated water containing 3.5 ppm ozone improves the efficiency of cleaning and disinfection in a pork cutting plant, increasing the proportion of free surfaces from $L$. monocytogenes by $12.5 \%$. Arayan et al. [11] showed that the lowest biocidal concentration against Staphylococcus aureus (strains isolated from food products) was $0.5 \mathrm{ppm}$ of ozone with an exposure time of $0.1 \mathrm{~min}$. The addition of organic pollutants such as fetal bovine serum (FBS) resulted in a decrease in the biocidal effectiveness of the ozonated water [11]. Also Korany et al. [28] showed lower efficacy of disinfectants, including ozonated water, in case of the presence of organic contamination (diluted milk and apple juice) in the environment.

The results of our study showed that after 1 and $2 \mathrm{~h}$ of storage of ozonated water its activity decreased, as evidenced by the need to use higher concentrations of ozone to eliminate L. monocytogenes strains after longer storage period of ozonated water. This was probably related to the decomposition of ozone, which is unstable and has a water stability of $20-40 \mathrm{~min}$. This is confirmed by the studies of Białoszewski et al. [12] who used ozonated water after $30 \mathrm{~min}$ of its preparation and observed a decrease in ozone concentration from the initial 2.5-3.0 $\mu \mathrm{g} / \mathrm{mL}$ to $1.3-1.5 \mu \mathrm{g} / \mathrm{mL}$. Despite the decrease in ozone content, they did not show a decrease in the biocidal effectiveness of water. Research carried out by Seki et al. [10] showed that storage of ozonated water at $4{ }^{\circ} \mathrm{C}$ and $25^{\circ} \mathrm{C}$ significantly affected its durability. The highest decrease $(90.0 \%)$ in ozone concentration was noticed after one week of storage at $25^{\circ} \mathrm{C}$. However, tests carried out at $4{ }^{\circ} \mathrm{C}$ by Seki et al. [10] showed that after one week the concentration of ozone in water maintained at the level of above $90 \%$, after a month about $65 \%$, and after one year of storage ozone was not found in water. The effect of biocidal ozonated water stored at $4^{\circ} \mathrm{C}$ against Escherichia coli has been confirmed. Seki et al. [10] also assessed the effect of freezing and thawing on the durability of ozone in water. They showed that the first freeze-thaw cycle did not affect the ozone concentration in water, but after four cycles it was found that the ozone concentration decreased to about $90 \%$ [10].

This study allowed to assess and compare the biocidal efficacy of solutions of thirteen selected disinfectants made using non-ozonated water and ozonated water against $L$. monocytogenes strains. It was shown that disinfectants based on ozonated water were characterized by higher microbicidal effectiveness, compared to solutions based on non-ozonated water and were more effective than ozonated water alone. This shows the synergistic effect of ozonated water and disinfectants. This may be related to the same target site of the test compound and ozone in bacterial cells. For example, QACs or peracetic acid act similarly to ozone, destabilizing the bacterial cell membrane, making it more permeable [31,32]. The synergistic mechanism of action can also be the result of influence of ozone and the active substance of the disinfectants on other structures of the bacterial cell, which will result in an increase of microbicidal effect. Oxidizing compounds (e.g., hydrogen peroxide, hypochlorous acid, 
and peracetic acid) cause the oxidation of thiol groups of cysteine residues, which are often found in the active sites of many bacterial enzymes, such as, for example, dehydrogenases.

It was found that the use of ozonated water for solution preparation, improves the microbicidal properties of all tested disinfectants, with the exception of nanosilver. The greatest impact of ozonated water on disinfectant effectiveness was noted for quaternary ammonium compounds. This type of disinfectants displayed the highest biocidal efficacy against tested isolates. The strong biocidal activity of quaternary ammonium compounds against L. monocytogenes strains is confirmed by the results of Chavant et al. [33], which showed $98 \%$ effectiveness in eliminating planktonic forms. In contrast, Aarnisalo et al. [34] have shown that quaternary ammonium compounds are characterized by lower biocidal efficacy against L. monocytogenes strains than disinfectants based on chlorine, ethanol, isopropanol and peracetic acid. In our study, the LMO-R strain was the most resistant to the effect of NANO 1, OA 2, and OA 3 preparations belonging to oxidizing compounds, and the LMO-M strain was the most resistant to the ChC 1 compound from the group of chlorine derivatives. The LMO-ATCC strain was characterized by the highest sensitivity against $\mathrm{ChC}$ 1. Heir et al. [35] and Popowska et al. [36] showed different sensitivity of L. monocytogenes to disinfectants depending on the origin of the strain.

The conducted studies also evaluated the durability of solutions with the lowest efficiency index for QAC 2, OA 3, and ChC 1. The decrease in the biocidal activity of disinfectant solutions prepared using non-ozonated water may suggest that they are gradually inactivated during storage.

The results of our study show that ozonated water have microbicidal properties. Since ozonated water and disinfectants show a synergistic effect of a biocidal action its combination can be used to more effectively eradicate microorganisms. Moreover ozonated water can reduce the working concentration of disinfectants. However, it is important to remember about the short half-life of ozone and to use it directly or in a short time after the preparation of appropriate disinfecting solutions.

To elucidate the mechanism of joint action of disinfectants and ozonated water on the disruption of bacterial cell structure further research are needed. In our study, the Columbia Agar with 5\% sheep blood was used, which is a non-selective medium. The use of such a medium provided suitable conditions for the regeneration of sub-lethal injured cells. Presence of selective and differential agents in a medium could inhibit the growth of such cells relative to non-selective medium and thus counts obtained from treated samples enumerated on selective media are typically lower than those obtained from non-selective media. This tendency is confirmed by studies by Fouladkhah et al. [37] who showed that when assessing the growth of bacteria on selective medium on day 0 the number of colonies ranged from $1.5 \pm 0.8$ to $2.0 \pm 0.8 \mathrm{log} \mathrm{CFU} / \mathrm{cm}^{2}$ and increased to values from $2.9 \pm 0.5$ to $4.3 \pm 0.4 \mathrm{log}$ $\mathrm{CFU} / \mathrm{cm}^{2}$ on 7 day. In turn, the results obtained after cultivation on non-selective media ranged from $2.0 \pm 0.5$ to $2.3 \pm 0.4 \log \mathrm{CFU} / \mathrm{cm}^{2}$ on day 0 and from $6.4 \pm 0.6$ to $7.1 \pm 0.4 \log \mathrm{CFU} / \mathrm{cm}^{2}$ on day 7 [37].

\section{Conclusions}

We can state that the ozonated water, in contrast to non-ozonated water, showed biocidal efficacy against examined L. monocytogenes strains though its activity decreases over time. Moreover, it was demonstrated that ozonated water improved the biocidal effectiveness of disinfecting agents. Among the tested solutions of disinfectant, the most effective group were quaternary ammonium compounds and chlorine compounds. The lowest biocidal activity against the tested strains of $L$. monocytogenes were characterized by nanoparticles. The biocidal activity of disinfectants against tested $L$. monocytogenes strains decreases during storage regardless of the disinfectant type.

Author Contributions: Conceptualization: K.S. and E.W.-Z.; Methodology: K.S., E.W.-Z., and M.K.; Validation: K.S., E.G.-K., and K.G.; Formal Analysis: S.K..; Investigation: K.G., A.B., N.W., A.B., and M.K.; Resources: K.S., E.W.-Z., and E.G.-K.; Data Curation: S.K., K.G., N.W., and A.B.; Writing-Original Draft Preparation: K.G., N.W., A.B., A.B., and M.K.; Writing-Review and Editing: K.S., E.W.-Z., and S.K.; Visualization: N.W., K.G., and A.B.; Supervision: K.S. and E.W.-Z.; Project Administration: K.S. and E.G.-K.; Funding Acquisition: E.G.-K. 
Funding: This research was financially supported by the Nicolaus Copernicus University with funds from the maintenance of the research potential of the Department of Microbiology DS-UPB.

Conflicts of Interest: The authors declare no conflict of interest.

\section{References}

1. Orsi, R.H.; Wiedmann, M. Characteristics and distribution of Listeria spp., including Listeria species newly described since 2009. Appl. Microbiol. Biotechnol. 2016, 100, 5273-5287. [CrossRef] [PubMed]

2. European Food Safety Authority (EFSA). The European Union summary report on trends and sources of zoonoses, zoonotic agents and food-borne outbreaks in 2017. EFSA J. 2018, 16, 5500.

3. Książczyk, M.; Krzyżewska, E.; Futoma-Kołoch, B.; Bugla-Płoskońska, G. Oddziaływanie związków dezynfekcyjnych na komórki bakteryjne w kontekście bezpieczeństwa higieny i zdrowia publicznego. Postępy Hig. Med. Dośw. 2015, 69, 1042-1055.

4. Demir, F.; Atguden, A. Experimental Investigation on the Microbial Inactivation of Domestic Well Drinking Water using Ozone under Different Treatment Conditions. Ozone-Sci. Eng. 2016, 38, 25-35. [CrossRef]

5. Wysok, B.; Uradziński, J.; Gomółka-Pawlicka, M. Ozone as an alternative disinfectant-A review. Pol. J. Food Nutr. Sci. 2006, 15, 3-8.

6. Alexopoulos, A.; Plessas, S.; Ceciu, S.; Lazar, V.; Mantzourani, I.; Voidarou, C.; Stavropoulou, E.; Bezirtzoglou, E. Evaluation of ozone efficacy on the reduction of microbial population of fresh cut lettuce (Lactuca sativa) and green bell pepper (Capsicum annuum). Food Control 2013, 30, 491-496. [CrossRef]

7. Elvis, A.M.; Ekta, J.S. Ozone therapy: A clinical review. J. Nat. Sci. Biol. Med. 2011, 2, 66-70. [CrossRef]

8. Thanomsub, B.; Anupunpisit, V.; Chanphetch, S.; Watcharachaipong, T.; Poonkhum, R.; Srisukonth, C. Effects of ozone treatment on cell growth and ultrastructural changes in bacteria. J. Gen. Appl. Microbiol. 2002, 48, 193-199. [CrossRef]

9. Khadere, M.A.; Yousef, A.E.; Kim, J.-G. Microbiological aspects of ozone applications in food: A review. J. Food Sci. 2001, 66, 1242-1252. [CrossRef]

10. Seki, M.; Ishikawa, T.; Terada, H.; Nashimoto, M. Microbidical Effects of Stored Aqueous Ozone Solution Generated by Nano-bubble Technology. In Vivo 2017, 31, 579-583. [PubMed]

11. Arayan, L.T.; Reyes, A.W.B.; Hop, H.T.; Xuan, H.T.; Yang, H.S.; Chang, H.H.; Kim, S. Optimized applications of ozonated water as an effective disinfectant for Staphylococcus aureus clearance in an abattoir setting. J. Prev. Vet. Med. 2017, 41, 71-74. [CrossRef]

12. Białoszewski, D.; Bocian, E.; Bukowska, B.; Czajkowska, M.; Sokół-Leszczyńska, B.; Tyski, S. Antimicrobial activity of ozonated water. Med. Sci. Monit. 2010, 16, 71-75.

13. European Committee on Antimicrobial Susceptibility Testing (2018) Breakpoints Tables for Interpretation of MICs and Zones Diameters. Version 8.0. Available online: http://www.eucast.org (accessed on 1 March 2019).

14. PN-EN 1276:2010. Chemiczne środki dezynfekcyjne i antyseptyczne-Ilościowa zawiesinowa metoda określania działania bakteriobójczego chemicznych środków dezynfekcyjnych i antyseptycznych stosowanych w sektorze żywnościowym, warunkach przemysłowych i domowych oraz zakładach użyteczności publicznej - metoda badania i wymagania (faza 2, etap 1). (In Polish). Available online: http://sklep.pkn.pl/pn-en-1276-2010e.html (accessed on 1 March 2019).

15. International Organization for Standardization (ISO). Water Quality-Determination of Free Chlorine and Total Chlorine-Part 2: Colorimetric Method Using N,N-dialkyl-1,4-phenylenediamine, for Routine Control Purposes; ISO: Geneva, Switzerland, 2017.

16. Kasprzyk-Hordern, B.; Ziółek, M.; Nawrocki, J. Catalytic ozonation and methods of enhancing molecular ozone reactions in water treatment. Appl. Catal. B Environ. 2003, 46, 639-669. [CrossRef]

17. American Public Health Association (APHA). Technical Committee on Microbiological Methods for Foods. In Compendium of Methods for the Microbiological Examination of Foods; APHA: Washington, DC, USA, 1984.

18. U.S. Food and Drug Administration (FDA). Bacteriological Analytical Manual; AOAC: Arlington, VA, USA, 2017.

19. Skowron, K.; Grudlewska, K.; Krawczyk, A.; Gospodarek-Komkowska, E. The effectiveness of radiant catalytic ionization in inactivation of Listeria monocytogenes planktonic and biofilm cells from food and food contact surfaces as a method of food preservation. J. Appl. Microbiol. 2018, 124, 1493-1505. [CrossRef]

20. Muthukumar, A.; Muthuchamy, M. Optimization of ozone in gaseous phase to inactive Listeria monocytogenes on raw chicken samples. Food Res. Int. 2013, 54, 1128-1130. [CrossRef] 
21. Sheelamary, M.; Muthukumar, M. Effectiveness of Ozone in Inactivating Listeria monocytogenes from Milk Samples. World J. Young Res. 2011, 1, 40-44.

22. Patil, S.; Valdramidis, V.; Frias, J.M.; Cullen, P.; Bourke, P. Ozone inactivation of acid stressed Listeria monocytogenes and Listeria innocua in orange juice using a bubble column. Food Control 2010, 21, 1723-1730. [CrossRef]

23. Sung, H.J.; Song, W.J.; Kim, K.W.; Ryu, S.; Kang, D.H. Combination effect of ozone and heat treatments for the inactivation of Escherichia coli O157:H7, Salmonella Typhimurium, and Listeria monocytogenes in apple juice. Int. J. Food Microbiol. 2013, 171, 147-153. [CrossRef] [PubMed]

24. Song, W.J.; Shin, J.Y.; Ryu, S.; Kang, D.H. Inactivation of Escherichia coli O157:H7, Salmonella Typhimurium and Listeria monocytogenes in apple juice at different $\mathrm{pH}$ levels by gaseous ozone treatment. J. Appl. Microbiol. 2015, 119, 465-474. [CrossRef] [PubMed]

25. Kumar, G.D.; Williams, R.C.; Sumner, S.S.; Eifert, J.D. Effect of ozone and ultraviolet light on Listeria monocytogenes populations in fresh and spent chill brines. Food Control 2016, 59, 172-177. [CrossRef]

26. Kang, S.N.; Kim, K.J.; Park, J.H.; Lee, O.H. Effect of a combination of low level ozone and metal ions on reducing Escherichia coli O157:H7 and Listeria monocytogenes. Molecules 2013, 18, 4018-4025. [CrossRef]

27. Marino, M.; Maifreni, M.; Baggio, A.; Innocente, N. Inactivation of Foodborne Bacteria Biofilms by Aqueous and Gaseous Ozone. Front. Microbiol. 2018, 9, 2024. [CrossRef]

28. Korany, A.M.; Hua1, Z.; Green, T.; Hanrahan, I.; El-Shinawy, S.H.; El-Kholy, A.; Hassan, G.; Zhu, M.J. Efficacy of Ozonated Water, Chlorine, Chlorine Dioxide, Quaternary Ammonium Compounds and Peroxyacetic Acid Against Listeria monocytogenes Biofilm on Polystyrene Surfaces. Front. Microbiol. 2018, 9, 2296. [CrossRef]

29. Fishburn, J.D.; Tang, Y.; Frank, J.F. Efficacy of Various Consumer-Friendly Produce Washing Technologies in Reducing Pathogens on Fresh Produce. Food Protect. Trends 2011, 32, 456-466.

30. Lariviere-Gauthier, G.; Letellier, A.; Quessy, S.; Fournaise, S.; Fravalo, P. Assessment of the efficiency of ozonated water as bacterial contamination reduction tool in a pork cutting plant. SafePork 2013, 42, 143-146.

31. Ioannou, C.J.; Hanlon, G.W.; Denyer, S.P. Action of disinfectant quaternary ammonium compounds against Staphylococcus aureus. Antimicrob. Agents Chemother. 2007, 51, 296-306. [CrossRef]

32. Leggett, M.J.; Schwarz, J.S.; Burke, P.A.; McDonnell, G.; Denyer, S.P.; Maillard, J.-Y. Mechanism of sporicidal activity for the synergistic combination of peracetic acid and hydrogen peroxide. Appl. Environ. Microbiol. 2016, 82, 1035-1039. [CrossRef]

33. Chavant, P.; Gaillard- Martine, B.; Hébraud, M. Antimicrobial effects of sanitizers against planktonic and sessile Listeria monocytogenes cells according to the growth phase. FEMS Microbiol. Lett. 2004, 236, 241-248. [CrossRef]

34. Aarnisalo, K.; Lundén, J.; Korkeala, H.; Wirtanen, G. Susceptibility of Listeria monocytogenes strains to disinfectants and chlorinated alkaline cleaners at cold temperatures. LWT 2008, 40, 1041-1048. [CrossRef]

35. Heir, E.; Lindstedt, B.A.; Røtterud, O.J.; Vardund, T.; Kapperud, G.; Nesbakken, T. Molecular epidemiology and disinfectant susceptibility of Listeria monocytogenes from meat processing plants and human infections. Int. J. Food Microbiol. 2004, 96, 85-96. [CrossRef]

36. Popowska, M.; Olszak, M.; Markiewicz, Z. Susceptibility of Listeria monocytogenes strains isolated from dairy products and frozen vegetables to antibiotics inhibiting murein synthesis and to disinfectants. Pol. J. Microbiol. 2006, 55, 279-288. [PubMed]

37. Fouladkhah, A.; Geornaras, J.; Sofos, J.N. Biofilm formation of O157 and Non-O157 Shiga toxin-producing Escherichia coli and multidrug-resistant and susceptible Salmonella Typhimurium and Newport and their inactivation by sanitizers. J. Food Sci. 2013, 78, 880-886. [CrossRef] [PubMed]

(C) 2019 by the authors. Licensee MDPI, Basel, Switzerland. This article is an open access article distributed under the terms and conditions of the Creative Commons Attribution (CC BY) license (http://creativecommons.org/licenses/by/4.0/). 